Portland State University

PDXScholar

Fall 1-7-2016

\title{
Sex-Specific Fungal Communities of the Dioicous Moss Ceratodon purpureus
}

Mehmet Ali Balkan

Portland State University

Follow this and additional works at: https://pdxscholar.library.pdx.edu/open_access_etds

Part of the Biology Commons, Fungi Commons, and the Plant Sciences Commons Let us know how access to this document benefits you.

\section{Recommended Citation}

Balkan, Mehmet Ali, "Sex-Specific Fungal Communities of the Dioicous Moss Ceratodon purpureus" (2016). Dissertations and Theses. Paper 2658.

https://doi.org/10.15760/etd.2654

This Thesis is brought to you for free and open access. It has been accepted for inclusion in Dissertations and Theses by an authorized administrator of PDXScholar. Please contact us if we can make this document more accessible: pdxscholar@pdx.edu. 
Sex-specific Fungal Communities of the Dioicous Moss Ceratodon purpureus

by

Mehmet Ali Balkan

A thesis submitted in partial fulfillment of the requirements for the degree of

Master of Science

in

Biology

Thesis Committee:

Todd N. Rosenstiel, Chair

Sarah M. Eppley

Daniel J. Ballhorn

Kenneth M. Stedman

Portland State University

2015 
(C) 2015 Mehmet Ali Balkan 


\section{Abstract}

Mosses display a number of hallmark life history traits that influence their ecology at the population and community level. The long lived separation of sexes observed in the haploid gametophyte (dioicy) is one such feature of particular importance, as it is observed in the majority of bryophytes and creates intraspecific specialization of male and female individuals.

The prevalence of sexually dimorphic mosses raises the possibility of sex-specific interactions with fungi as observed in some vascular plants. Here I investigated how moss sex shapes fungal communities associated with gametophytic tissues of the ubiquitous moss, Ceratodon purpureus. Using greenhouse populations of $C$. purpureus grown in a common garden, I examined fungal community structure and overall abundance of fungal biomass associated with male and female individuals from multiple populations. I hypothesized that individual mosses would harbor unique fungal communities based on their sex, and that overall fungal biomass associated with host tissues would differ significantly due to differences in morphological and physiological characteristics between the sexes. I found that fungal community composition and overall abundance (i.e. biomass) differ between male and female individuals of $C$. purpureus, and that sex-specific patterns are retained across individuals from three different populations. This work provides a first glance at how genetically based sexual systems in early land plants influence affiliated fungal community composition. 


\section{Acknowledgments}

One's journey through academic science rarely happens in isolation, and to the contrary is a collaboration of the minds and hearts of so many. I cannot thank enough my parents, who have always encouraged me to follow my own path and discover my passions, whatever they may be. Their courage, steadfastness, patience, openness, and love continue to inspire me to be better and to strive for the betterment of the world around me. I am also greatly indebted to my brother whose guidance and support have been indispensible through the years. He is truly the only one who has real insight into my personal development and existential perspective. We have walked together with a foot in two very different worlds, never really feeling at home except when in motion. I am grateful for a family that has helped me to navigate through personal, social, political, and academic challenges with elegance and honesty.

I would like to thank Dr. Todd Rosenstiel and Dr. Sarah Eppley for helping me see many different facets of the same gem. The collective guidance and creativity I have experienced as their student has shaped my thinking and flavored my science. I feel lucky to have had the freedom to pursue my interests in their group, where random strokes of inspiration that may have seemed tangential to some were recognized as the beginnings of great stories. I would also like to thank Dr. Daniel Ballhorn, Dr. Ken Stedman, and Dr. Peter Kennedy for their critical mentorship. I honestly feel as though I had an advisory team; so 
many brilliant minds that have contributed to the development of my approach to science, and helped to refine my perspective. My time in the Rosenstiel-Eppley Complex was significantly influenced by all the exceptional individuals I had the pleasure and honor of working with. First and foremost, I must thank Mandy Slate, who introduced me to the lab as a volunteer and initiated my interest in bryophytes. Mandy's support, encouragement, science brain, and friendship were instrumental in my process. I am also beholden to the rest of our team and other fellow grad students: Matt Chmielewski, Jason Maxfield, Hanah Prather, Erin Shortlidge, Scott Kiel, Laura Holloway, Timea Deakova, Cody Whol, Brett Younginger, Natasja Swartz, Rob Jensen, Chase Reinhart, Nick Day and many others. Thank you all for the laughs, the graphs, and the Pabsts! You have been my second family (of nerds). I would also like to acknowledge the faculty and staff of the biology department at PSU, who make up all the little pieces of the puzzle. This thesis would not have been possible without the love, patience, support, and scientific perspective of my sweetheart Amie Lynn Romney. Your thoughtful feedback and provision of snacks, coffee, and hugs kept me on my feet through this journey. 


\section{Table of Contents}

$\begin{array}{ll}\text { i } & \text { Abstract } \\ \text { ii } & \text { Acknowledgements } \\ \text { v } & \text { List of Tables } \\ \text { vi } & \text { List of Figures }\end{array}$

1 Chapter 1: Introduction

1 Patterns in Ecological Communities

3 Bryophytes: a Brief Introduction

$5 \quad$ Bryophytes as Foundation Species

7 Fungal Components of the Bryosphere

9 Bryophyte Reproductive Ecology

12 Ceratodon purpureus

13 Goals of this thesis

\section{Chapter 2: Materials and Methods}

15 Study system

16 DNA extraction and PCR

17 T-RFLP analysis

17 T-RFLP data processing

18 Fungal biomass estimation

19 Statistical analysis

\section{Chapter 3: Results}

21 Fungal community composition

30 Fungal biomass estimates

\section{Chapter 4: Discussion}

\section{$41 \quad$ References}




\section{List of Tables}

21 Tables 1a, 1b. Permutational multivariate analysis of variance between fungal community profiles generated by Hae III and Hinf I

29 Table 2. Non-parametric diversity estimators of fungal diversity

32 Table 3. Results of two-way ANOVA for ergosterol concentration in moss tissues as influenced by host sex (male and female) and population $(\mathrm{NH}$, $35^{\text {th }}$, and UCUT).

32 Table 4. Results of post-hoc Tukey HSD test showing pairwise differences in mean ergosterol concentration between populations $\left(\mathrm{NH}, 35^{\text {th }}\right.$, and UCUT). 


\section{List of Figures}

22 Figures 1a. NMDS ordination of Hae III fungal community profiles by sex

23 Figures 1 b. NMDS ordination of Hae III fungal community profiles by sex and population

24 Figure 2a. NMDS ordination of Hinf I fungal community profiles by sex

25 Figure 2 b. NMDS ordination of Hinf I fungal community profiles by sex and population

27 Figure 3. Rarefaction and extrapolation curves of fungal community profiles generated by Hae III restriction based T-RFLP

28 Figure 4. Rarefaction and extrapolation curves of fungal community profiles generated by Hinf I restriction based T-RFLP

30 Figures 5a. Ergosterol concentration in tissues of $C$. purpureus by sex

$31 \quad$ Figures $5 \mathrm{~b}$. Ergosterol concentration in tissues of $C$. purpureus by sex and population 


\section{Chapter 1: Introduction}

\section{Patterns in Ecological Communities}

All life on earth coexists not only within populations of the same species, but with many other species groups forming interactive living collectives known as communities. Communities operate based on complex, intersecting, and rarely discrete principles referred to as assembly rules (Diamond, 1975; Keddy, 1992; Weiher \& Keddy, 2001) that influence their functionality, stability, and longevity. These governing principles should not be viewed simply as black and white rules of engagement, but as theoretical frameworks to describe and measure community dynamics that are based on commonly observed phenomena. In the modern approach, four main processes make up the umbrella under which assembly rules unfold: selection, drift, speciation, and dispersal (Vellend, 2010). These four pillars of community ecology may be familiar as they are reflections of "the big four" in population genetics. Consideration of each of the four processes is important but here a primary focus on selection will be pursued. In particular, a suite of selective elements defined in part by external species interactions called ecological filters is considered.

The structure and functional attributes of biological communities are governed in part by ecological or environmental filters (biotic and abiotic) that collectively act to shape assembly trajectories (Keddy, 1992; Kelt et al., 1995; 
Diaz et al., 1998). Species interactions are among the most important filters shaping communities and are often hierarchically structured (Baumeister \& Callaway, 2006; Kunstler et al., 2012), reflecting their relative strength in influencing community outcomes. Within this continuum, foundation species are those members of a community whose disproportionately large effect on community processes can cause shifts in diversity and structure (Ellison et al., 2005; Bangert et al., 2006; Angelini et al., 2011; Schöb et al., 2012). In tandem with the robust development of our understanding of foundation species, a new movement has begun in which the synergy between evolutionary biology and ecology has come to a new level (Johnson \& Stinchcombe, 2007). The genes-toecosystem or community genetics approach seeks to understand how genetic properties of individuals and populations can manifest as phenotypic traits that emanate through different organizational levels up to the ecosystem level (Shuster et al., 2006; Whitham et al., 2006; Bangert et al., 2006). In this emerging field, the traditional individual phenotype is expanded to encompass a predictable and heritable community phenotype: the result of certain critical traits of the foundation species that have a strong genetic basis. Perhaps the best documented example of heritable community phenotypes in action is in the Populus system (Whitham et al., 2006). In this system the poplar tree acts as a foundation for multitrophic communities, and variation in certain aspects of leaf chemistry-controlled by a single quantitative trait locus-across individual poplar genotypes have been shown to create cascading effects across each level of the 
community examined. In this particular case fungal endophyte, arthropod, and aquatic macroinvertebrate communities associated with poplars vary predictably in their composition based on condensed tannin levels in the leaves of different host genotypes (Wimp et al., 2005; Bailey et al., 2005). These studies and others (Dungey et al., 2000; Whitham et al., 2003; Hochwender \& Fritz, 2004; Johnson \& Agrawal, 2005; Brändle \& Brandl, 2006; Tovar-Sánchez \& Oyama, 2006), highlight the power of community genetics to uncover how the genetic basis of foundation species traits can influence community dynamics at different levels, and thus aid in the characterization of assembly rules. However, it is critical to continue developing this approach with consideration for other traits and further experimentation in other systems. Bryophytes present one such promising model system for the study of foundational traits in communities. Certain features of this group such as their reproductive systems and unique genetic architecture, in addition to their prominent roles within ecological communities, support this prospect and are further discussed in the following sections.

\section{Bryophytes: A Brief Introduction}

Bryophytes are an ancient lineage of plants that represent the closest extant relatives of the first terrestrial plants and are widely distributed across most ecosystems on earth (Herzog, 1926; Kenrick \& Crane, 1997). Thought to have originated as early as the mid Ordovician period (Wellman \& Gray, 2000; 
Rubinstein et al., 2010), the bryophytes are composed of three major groups; the liverworts (Marchantiophyta), the hornworts (Anthocerotophyta), and the mosses (Bryophyta), the later of which boasts the greatest diversity with over 12,000 described species (Shaw et al., 2005). Bryophytes exhibit a number of unique morphological and physiological traits that truly set them apart from other embryophytes. These traits include extreme desiccation tolerance (poikilohydry), lack of complex vasculature and true roots, a haploid-dominant life cycle, and a large proportion of dioicous (dioecious haploids) species, among others. Bryophytes have maintained their ancient lifestyle across many evolutionary epochs with little deviation, embodying evidence for truly successful strategies that have persisted alongside the explosion of vascular plant diversity in later periods (Shaw et al., 2011). Additionally, over the course of their evolutionary history bryophytes have developed highly complex relationships with other biota such as mutualistic associations with nitrogen-fixing cyanobacteria (Lindo et al., 2013), fungi (Davey \& Currah, 2006), and a potential pollinator like syndrome with collembola (Rosenstiel et al., 2012), among others. Through some of these relationships and their own biophysical and physiological properties, bryophytes can have a major influence on their surrounding environment, in some cases on a global scale. The section that follows details some of the ways in which bryophytes 'engineer' abiotic and biotic elements of communities and ecosystems, further underscoring their utility as a model system in community ecology. 


\section{Bryophytes as Foundation Species}

Owing to their distinctive lifestyles among land plants, bryophytes fulfill unique ecological roles in ecosystems; acting as pioneer species that are some of the first plants to colonize disturbed habitats, and often growing in places and under conditions that other plants cannot (Vanderpoorten \& Goffinet, 2009). Bryophytes, and in particular mosses, contribute a number of critical ecosystem services to the environs they inhabit (Turetsky, 2003; Cornelissen et al., 2007; Lindo \& Gonzalez, 2010; Turetsky et al., 2012). Among the most notable contributions of mosses are their capacity to support diverse, multitrophic, biological communities (Lindo \& Gonzalez, 2010), influence nitrogen and phosphorus cycling at a landscape scale (Chapin III et al., 1987; Turetsky, 2003; Cornelissen et al., 2007; Rousk et al., 2014), augment abiotic soil conditions such as moisture, temperature, and redox potential, and make significant contributions to net primary productivity in many terrestrial systems (Longton, 1992; Gornall et al., 2007; Blok et al., 2011; Rousk et al., 2014). The role of mosses in global change biology is perhaps best documented in peatland systems where the genus Sphagnum dominates and is responsible for the storage of more than one third of the worlds terrestrial carbon (Loisel et al., 2012). Though peatlands have long served as the model system for studying 'bryogeochemistry’ (Damman, 1986; Gorham, 1991; Dunfield et al., 1993; Kang et al., 2001; Turetsky et al., 2002; Loisel et al., 2012), an ever-growing body of work is highlighting the global importance of the Bryosphere in many other 
systems including Antarctica (Pressel, 2009), the Arctic (Longton, 1997), and boreal and temperate forests (DeLucia et al., 2003; Turetsky et al., 2012).

Due to their disproportionately large ecological influence mosses can be considered as foundation species (Whitham et al., 2006; Lindo \& Gonzalez, 2010; Tuba et al., 2011). This foundational capacity of the mosses is especially evident in a community ecology context, whereby the moss acts as critical host to a multitude of other life forms ranging from bacteria, fungi, and protists, to tardigrades, rotifers, mites, springtails and other invertebrates. This biologically rich, and dynamic matrix is collectively referred to as the Bryosphere, and is an integral component of global detrital systems that drive biogeochemical cycling (Lindo \& Gonzalez, 2010). Microbial constituents of the bryosphere are of particular interest as they represent a more basal level of the trophic web, and have far reaching functional influence. Though some microbial components of the bryosphere such as cyanobacteria (Adams \& Duggan, 2008; Lindo et al., 2013; Arróniz-Crespo et al., 2014; Stuiver et al., 2015) have been relatively well studied, the factors that drive relationships with other major players-specifically fungi-are still largely unknown. The prevalence of the fungi in the bryosphere (Davey \& Currah, 2006) beckons more attention to the study of this relationship. What follows is a brief survey of what we know about moss-fungi interactions. 


\section{Fungal Components of the Bryosphere}

The bryosphere is an integrated detrital network driven by multitrophic communities that operate on a host bryophyte framework. Like other detrital systems, microbial activity is at the core of the bryosphere. In particular, taxonomically and functionally diverse fungal components have been observed to influence the bryosphere through a spectrum of interactions with host mosses ranging from seemingly mutualistic to parasitic, though the nature of interaction between the vast majority of bryophillous fungi and their hosts has yet to be revealed (Davey \& Currah, 2006; Kauserud et al., 2008; Davey et al., 2009, 2012b). Members of all five major fungal lineages have been observed inhabiting the moss phyllosphere, constituting functionally diverse assemblages (Davey et al., 2012b) that have the propensity to drive ecosystem processes (Christensen, 1989). Within the vast diversity of bryophilous fungi, members of the phylum Ascomycota appear to be the dominant group in most reports (Felix, 1988; Döbbeler, 2002; Davey \& Currah, 2006; Kauserud et al., 2008; Ptaszyńska et al., 2009; Davey et al., 2012a,b; Döbbeler \& Hertel, 2013). Furthermore, many bryophilous ascomycetes are highly specialized to specific parts of moss hosts (e.g. rhizoids, hyaline hair points, apical stems)(Döbbeler, 2002; Ptaszyńska et al., 2009; Döbbeler \& Hertel, 2013). A study by Döbbeler et al. (2009) found phylogenetic evidence for multiple origins of specialized bryophyte-ascomycte associations, underscoring the intimate coevolution of bryophytes and fungi. Another example of a highly specialized, ancient bryophyte-fungi interaction is 
the relationship between arbuscular mycorrhizal fungi (AMF) and some bryophytes (Read et al., 2000; Ligrone et al., 2007; Wang et al., 2010; Desirò et al., 2013). As in vascular plants, AMF form a symbiotic association with bryophytes that enables enhanced nutrient uptake by the host through fungal hyphae infecting the host's tissues in exchange for photosynthetically derived carbon that is translocated to the fungus (Read et al., 2000; Ligrone et al., 2007; Desirò et al., 2013; Pressel et al., 2014). These mutualisms have been well documented in the liverworts (Marchantiophyta) and hornworts (Anthocerotophyta), and although AMF have been previously observed in the tissues of mosses (Rabatin, 1980; Parke \& Linderman, 1980; Zhang \& Guo, 2007), there is as of yet no evidence that functional mutualisms exist between AMF and mosses suggesting that mosses may have unique interactions with fungi relative to other bryophytes. Despite a growing body of knowledge regarding the interactions between bryophytes and fungi, investigations of whole fungal communities associated with bryophytes are scarce (Kauserud et al., 2008; Davey et al., 2012a,b). A handful of recent studies have provided insight into some of the factors influencing the structural characteristics of mossassociated fungal communities (Davey et al., 2012a,b), but further investigation is needed to refine our understanding of how unique biological features of bryophytes influence their interactions with fungi in a fundamentally different way than vascular plants. The reproductive biology of mosses offers an exceptional opportunity to examine how a distinctive, ecologically important set of traits in 
bryophytes can be a formative force in shaping interactions with fungi in the bryosphere. An exploration of these reproductive traits will reveal their potential to act as biotic filters for community assembly.

\section{Bryophyte Reproductive Ecology}

Given the complexities of bryophyte reproductive ecology, first I will discuss some fundamental concepts in bryophyte reproduction and how some special features make for unique biotic interactions. Bryophyte reproduction involves a dominant stage that is opposite of their vascular cousins. The haploid gametophyte dominates the majority of the life cycle and at maturity bears sexual structures called archegonia (females) and antheridia (males). In dioicous bryophytes, these structures appear on separate individuals. When sexual structures reach maturity, biflagellate sperm produced in the antheridia swim across water films on the surface of gametophytes in search of the female ovum. Sperm cells are guided towards their female counterparts by sucrose gradients released from the archegonia (Pfeffer, 1884). When fertilization is successful, a diploid sporophyte begins to develop and is largely nurtured by the maternal gametophyte. It is within the developing sporophyte that meiosis occurs producing haploid spores of distinct sex. Spores are released from the mature sporophyte and viable individuals germinate to produce the primary stage of bryophyte life: chlorotic, filamentous networks called protonema. The protonemal networks function in a fashion similar to a fungal mycelium or vascular plant's 
root mass: branching out and extending in many directions to seek out nutrition and water. When ideal conditions are met the protonemal network begins to restructure into a denser, often initially thalate, gametophytic tissue matrix, returning once again to the beginning of the bryophyte life cycle (Vanderpoorten \& Goffinet, 2009).

As with most other species that are unisexual, male and female bryophytes display a host of sex-specific traits that influence their relationships with the external environment and biota. The occurrence of sexually dimorphic ecology is widespread and well documented in the animal kingdom (Darwin, 1871; Lailvaux \& Vincent, 2007), but its implications for plants have only recently begun to be appreciated (Eppley et al., 2009; Varga, 2010; Petry et al., 2013; Vega-Frutis et al., 2013), and have likely been mostly overlooked due to the small proportion of vascular plants that maintain separate sexes (Renner \& Ricklefs, 1995). Sexual dimorphisms present a unique form of intraspecific trait diversity that is inherently tied to reproductive fitness, but whose influence can extend beyond the context of reproduction. The literature describing the dimorphic ecology of dioecious angiosperms demonstrates that male and female individuals interact with and change their biotic and abiotic environment in different ways. For example, males and females typically have different resource requirements and allocation patterns which can directly and specifically influence their physical distribution and success in heterogeneous environments (Bierzychudek \& Eckhart, 1988). Furthermore, sex-specific differences in 
beneficial biotic interactions such as those involving mycorrhizal fungi (Eppley et al., 2009; Varga, 2010), as well as antagonistic interactions, such as those involving herbivores and pathogens (Ågren et al., 1999; Vega-Frutis et al., 2013), have the potential to not only shape populations of the plants in question but also that of the interacting biota. In contrast to their vascular relatives, bryophytes exhibit a much greater degree of dioicy with over $60 \%$ of taxa producing separate sexes (Wyatt \& Anderson, 1984), and thus the potential for sex-specific biotic interactions is much higher in bryophytes.

Bryophytes are typically sexually dimorphic and can have skewed distributions in natural populations (Fuselier \& Stark, 2004; Stark et al., 2010). Important sex-specific physiological and morphological differences such as size (Shaw \& Beer, 1999), prezygotic investment (Horsley et al., 2011), time to sexual maturity (Stark, 2002), and emission of volatile organic compounds (VOCs) (Rosenstiel et al., 2012), have been observed in bryophytes. Furthermore, bryophytes possess unique sex chromosomes on which crossing over is completely suppressed (Bachtrog et al., 2011); contributing greatly to the accumulation of sexually antagonistic traits in the haploid gametophyte stage predominant in the bryophyte life cycle (McDaniel \& Perroud, 2012). Such extreme sex-based genetic partitioning supports the prospect of intraspecific differences in ecological interactions based on sex. Recently, Rosenstiel et al. (2012) found that common microinvertebrate inhabitants of the moss Ceratodon purpureus were disproportionately attracted to volatile compounds emitted by 
female individuals. Further, the study revealed that overall volatile organic compound (VOC) emissions formed distinct profiles among males and females. These findings coupled with others showing increased fertilization events with the addition of collembolans to patches of $C$. purpureus suggest a possible pollinatorlike syndrome in the mosses, adding an additional layer of complexity to bryophyte reproduction

With the interest of exploring the prospect of other sexually dimorphic ecological interactions, the moss Ceratodon purpureus is an excellent candidate species to be used as a model. In addition to the sex-specific biotic interactions already observed in this species mentioned above, a number of other critical features bring $C$. purpureus to center stage as an ideal subject for further elucidating how a genetically based like sex may influence other community components such as fungi.

\section{Ceratodon purpureus}

Ceratodon purpureus is a dioicous, acrocarpous moss in the family Ditrichaceae with a cosmopolitan distribution across all continents including Antarctica (McDaniel \& Shaw, 2005). C. purpureus is often found growing in urban environments, poor soils, and recently burned areas, and evidently is tolerant of a wide range of environmental conditions including soils laden with heavy metals (Jules \& Shaw, 1994) and extreme UV (Clarke \& Robinson, 2008). 
For many years $C$. purpureus has been used a model to study physiology (Algarra et al., 1993; Kohn et al., 1994), population genetics (Skotnicki et al., 2004; McDaniel, 2005; McDaniel et al., 2007), and sexual ecology (Shaw \& Gaughan, 1993; Shaw \& Beer, 1999; Rosenstiel et al., 2012). Along with the recent effort to sequence its genome (http://jgi.doe.gov/why-sequence-ceratodonpurpureus-moss/), and an increasing understanding of its general ecology, $C$. purpureus is increasingly becoming a robust model system for studying community dynamics in the bryosphere.

\section{Goals of this thesis}

Expanding our understanding of the nature of biological communities and the forces that shape them is a central goal of ecology that has far reaching implications in many other fields. The genes to ecosystem approach, which is focused on tracking how the genomic patterns of foundation species can have cascading effects across different levels of a community, shows great promise in untangling the basis of assembly rules in a manner in which traditional approaches to community ecology can not. Bryophytes present an exceptional model for the study of community genetics because of their foundational roles within the complex, multitrophic communities, as well as unique genomic features that allow an unobscured view into traits that influence these communities. Specifically, the dominant haploid gametophyte life stage coupled with a distinctive sex chromosomal system in dioicous species permits the observation 
of genetically rooted, sex-specific traits directly in the individual phenotype. While a small but growing number of studies have begun to elucidate how plant sex influences biotic interactions in vascular systems, remarkably few focus on other prolific groups such as the bryophytes. Furthermore, to my knowledge, there are no studies investigating how plant sex structures microbial communities (as opposed to individual interactions) in any part of the kingdom. Given the wellestablished importance of dynamics in the plant-microbe continuum in global processes, unveiling the basis of these dynamics remains a critical task in community ecology.

The goals of the research presented herein are to investigate how sex as a concrete, genetically governed trait in a haplodioicous foundation species influences the composition and overall biomass of associated fungal communities. I predict that both community composition and biomass will differ between fungal communities associated with males and females due to sexually dimorphic characteristics. 


\section{Chapter 2: Materials and Methods}

Study System

Greenhouse populations of $C$. purpureus were generated using tissue collected from three geographically isolated populations. Two of the populations were within the urban boundaries of Portland, OR: Neuberger Hall $(\mathrm{NH})$ $\left(45^{\circ} 30^{\prime} \mathrm{N}, 122^{\circ} 41^{\prime} \mathrm{W}\right)$, located on the downtown campus of Portland State University, and Northeast $35^{\text {th }}\left(35^{\text {th }}\right)\left(45^{\circ} 32^{\prime} \mathrm{N}, 122^{\circ} 37^{\prime} \mathrm{W}\right)$, located $8 \mathrm{~km}$ northeast of downtown. The third population (UCUT) $\left(45^{\circ} 36^{\prime} \mathrm{N}, 123^{\circ} 0^{\prime} \mathrm{W}\right)$ was located $32 \mathrm{~km}$ west of the Portland metropolitan area. Climatic conditions were similar in all three sites where C. purpureus was found growing on moderately heavy clay soils with a shallow organic horizon. Single intact shoots $(\sim 2 \mathrm{~cm})$ from 8 sexually expressing males and females from each population were vegetatively propagated in $10 \mathrm{~cm}^{2}$ pots on growth media composed of 2:1 peat/sand (Sun Gro). Pots containing males and females were organized in blocks with $\sim 2 \mathrm{~cm}$ between pots within two separate trays, and rotated regularly to avoid tray effects. A plastic barrier was placed between benches housing males and females to prevent fertilization events. Mosses were grown for $\sim 2$ years in common garden under semi-exposed greenhouse conditions that were not completely isolated from the external environment, but likely had more limited exposure to fungi than mosses growing outdoors. Temperatures were typically within $2^{\circ} \mathrm{C}$ of outside temperatures. Pots were misted from above with tap water 
four times per day for 2 minutes, at 6 -hour intervals by an automated irrigation system.

\section{DNA Extraction and PCR}

Total DNA was extracted from single shoots of $C$. purpureus using the REDExtract-N-Amp Tissue PCR Kit (Sigma-Aldrich) according to the manufacturer's protocol with the following changes: moss shoots were submerged in $20 \mu \mathrm{l}$ of 1:4 tissue preparation and extraction solutions and incubated at $\mathrm{RT}$ for $10 \mathrm{~min}$ followed by $10 \mathrm{~min}$ at $95^{\circ} \mathrm{C}$, and $10 \mathrm{~min}$ at $65^{\circ} \mathrm{C}$. Following incubation, $20 \mu \mathrm{l}$ of neutralization solution was added to each sample and mixed by pipetting. All residual plant material was physically removed from finished extractions using sterile pipette tips. Finished extractions were subsequently stored at $4^{\circ} \mathrm{C}$. The fungal ITS region was amplified by PCR using primers ITS1F and ITS4 in duplicate $20 \mu \mathrm{l}$ reactions containing $10 \mu \mathrm{l}$ REDExtractN-Amp PCR Reaction Mix (Sigma-Aldrich), $0.4 \mu \mathrm{l}$ 6-FAM labeled forward primer ITS1F (CTTGGTCATTTAGAGGAAGTAA), $0.4 \mu$ reverse primer, ITS4 (TCCTCCGCTTATTGATATGC), $1 \mu \mathrm{l}$ template DNA, and $8.2 \mu \mathrm{I}$ PCR $\mathrm{H}_{2} 0$ ).

Reactions were run in a Bio-Rad DNA Engine ${ }^{\circledR}$ thermal cycler (Bio-Rad Laboratories) under the following cycling conditions; $94^{\circ} \mathrm{C}$ for $1 \mathrm{~min}, 35$ cycles of $94^{\circ} \mathrm{C}$ for $1 \mathrm{~min}, 53^{\circ} \mathrm{C}$ for $1 \mathrm{~min}, 72^{\circ} \mathrm{C}$ for $1 \mathrm{~min}$, and 1 cycle at $72^{\circ} \mathrm{C}$ for $8 \mathrm{~min}$. PCR products from duplicate reactions were combined and purified using an 
UltraClean PCR Clean-Up Kit (Mo Bio Laboratories), and clean PCR products stored at $4^{\circ} \mathrm{C}$ until further use.

\section{T-RFLP Analysis}

Restriction digests were prepared in $20 \mu$ reactions containing $12 \mu \mathrm{l}$ purified PCR products, $1 \mu \mathrm{l}$ restriction enzymes Hae III or Hinf I (Thermo Fisher Scientific), $2 \mu \mathrm{l}$ digest buffer, and $5 \mu \mathrm{PCR} \mathrm{H}_{2} \mathrm{O}$. Digests were incubated at $37^{\circ} \mathrm{C}$ for 4 hours, followed by a 20 minute deactivation period at $80^{\circ} \mathrm{C}$. Digest products were purified using an UltraClean PCR Clean-Up Kit (Mo Bio Laboratories) and stored at $4^{\circ} \mathrm{C}$. Clean digest products were transferred to a 96-well plate, concentrated in a Savant SpeedVac (Holbrook, NY), and shipped to OSU CGRB Core Labs for fragment analysis. Samples were resuspended in .9 $\mu \mathrm{Hi}-\mathrm{Di}$ formamide and $.1 \mu \mathrm{l}$ MapMarker 1000 fluorescent standard and analyzed on an $\mathrm{ABI} 3730$ sequencer. Resulting fluorescent terminal restriction fragment (fTRF) lengths were determined using GeneMapper 5 software (Life Technologies).

\section{T-RFLP Data Processing}

All fungal community profiles (electrophoretograms) were manually inspected and peaks smaller than 50bp and larger than $800 \mathrm{bp}$ were removed to reflect the range in which the MapMarker 1000 standard can be used to accurately predict fragment sizes. In order to distinguish true peaks representing fungal OTUs from noise, raw fragment analysis data were refined using the 
constant percentage threshold technique whereby all peaks whose percent area contribution to the total area of a profile fell below $0.5 \%$ were discarded prior to further analysis. I found that using a percentage threshold below $1 \%$ yielded more accurate results by increasing the detection of relatively less abundant fTRFs (see Blackwood et al., 2007). All remaining peaks were aligned to $1 \mathrm{bp}$ using the Treeflap macro (http://www.sci.monash.edu.au/wsc/staff/walsh/treeflap.xls) in Excel. Global singletons (fTRFs occurring only once within the entire dataset) were removed prior to ordination and similarity analyses to minimize the inclusion of PCR artifacts and miscalled electrophoretic reads (fTRF drift) (Culman et al., 2008). All qualified fTRFs were compiled into presence-absence matrices based only on occurrence, since methodological limits of T-RFLP do not allow for accurate estimation of OTU abundance based on fluorescence intensity (Schütte et al., 2008).

Fungal Biomass Estimation by Ergosterol Quantitation

Whole gametophytes of each C. purpureus individual were collected, washed thoroughly in deionized water to remove soil and coarse debris, frozen at $-80^{\circ} \mathrm{C}$ for $48 \mathrm{hrs}$, and lyophilized. $100-200 \pm 0.1 \mathrm{mg}$ of lyophilized tissue was placed in $2 \mathrm{ml}$ microcentrifuge tubes with one $3 \mathrm{~mm}$ zirconium bead and ground to a fine powder using a bead beater at 2500 RPM for 40 seconds. Ergosterol was extracted from powdered tissues following the methods of Dahlman et al. 
(2002) with the following changes. Samples were suspended in $1 \mathrm{ml} \mathrm{HPLC} \mathrm{grade}$ $\mathrm{MeOH}$, agitated in an orbital shaker for $1 \mathrm{hr}$ at $320 \mathrm{RPM}$ in darkness, and subsequently allowed to precipitate overnight at $4^{\circ} \mathrm{C}$. Extractions were then centrifuged for $1 \mathrm{hr}$ at $14,000 \mathrm{RPM}$ and $4^{\circ} \mathrm{C}$ in an Eppendorf Centrifuge 5402. Following centrifugation, the supernatant from each extraction was transferred to a fresh $2 \mathrm{ml}$ microcentrifuge tube and centrifuged for an additional $10 \mathrm{~min}$ at 14,000 RPM and $4^{\circ} \mathrm{C}$ (Eppendorf Centrifuge 5402). The supernatants from this secondary centrifugation were filtered through $0.2 \mu \mathrm{m}$ acrodiscs into amber autoanalyzer vials and stored at $4^{\circ} \mathrm{C}$ until HPLC analysis. Extractions were analyzed following Davey et al. 2012 on an 1100 Series HPLC (Agilent Technologies, Waldbronn, Germany). The limit of detection was $5.59 \mu \mathrm{g}$.

\section{Statistical Analysis}

The compositional similarity between individual communities was estimated by calculating Bray-Curtis dissimilarity values (Bray \& Curtis, 1957), which were consequently ordinated by non-metric multidimensional scaling (NMDS). Compositional differences between fungal communities associated with male and female C. purpureus individuals were statistically compared by analysis of similarity (ANOSIM) and permutational multivariate analysis of variance (PERMANOVA). OTU richness estimates and extrapolation were performed using Mao Tau, Chao2, and ICE estimators. The Mao Tau algorithm allows the calculation of estimated species richness based on an infinite number of 
randomized resampling schemes during sample-based rarefaction (Colwell et al., 2004). The non-parametric asymptotic species richness estimators Chao2 and ICE, were chosen based on their sensitivity to rare species (Chao, 1987; Lee \& Chao, 1994), and because they do not assume any particular species abundance distributions making them suited for incidence based data. To assess the robustness and adequacy of sampling efforts to capture overall diversity of the sampled communities, sample completeness, sample-size-based, and coveragebased rarefaction and extrapolation curves were generated using Hill numbers according to Chao et al. (2014) using the iNEXT package for R. The influence of sex, population, and the interaction between sex and population on ergosterol concentration in moss tissues was assessed by two-way ANOVA. A post-hoc Tukey HSD test $(p<0.05)$ was performed in order to determine significant differences between populations. All statistical analyses were performed using $R$ statistical environment v. 3.0.2 (R Development Core Team, 2008) and EstimateS v. 8 software (Colwell, 2013). 


\section{Chapter 3: Results}

Fungal Community Composition

Fungal community composition was statistically significantly different

based on C. purpureus sex in TRFLP community profiles generated by both Hae

III and Hinf I restriction enzymes (ANOSIM: R=0.134, $p=0.003 ; \mathrm{R}=0.102$,

$p=0.006$, respectively). PERMANOVA analyses further support statistically

significant differences between fungal community composition based on sex and

population (Tables 1a, 1b).

Table 1a. Permutational multivariate analysis of variance between fungal community profiles generated by Hae III. Differences between communities associated with male $(n=23)$ and female $(n=24)$ individuals from three different populations $\left(\mathrm{NH}, 35^{\text {th }}\right.$, UCUT). Values for degrees of freedom (df), sum of squares (SS), mean squares (Mean Sq), F-ratio (F), r-squared $(\mathrm{R} 2)$, and $p$-value $(p)$ are displayed. Bold values indicate statistical significance.

\begin{tabular}{lcccccc}
\hline Hae III & $d f$ & $S S$ & Mean Sq & $F$ & $R 2$ & $p$ \\
\hline Sex & 1 & 0.83 & 0.83 & 3.48 & 0.07 & $\mathbf{0 . 0 0 2}^{\text {** }}$ \\
Population & 2 & 0.88 & 0.44 & 1.85 & 0.07 & $\mathbf{0 . 0 1 2}^{\star}$ \\
Sex x Population & 2 & 0.52 & 0.26 & 1.11 & 0.04 & 0.318 \\
Residuals & 40 & 9.52 & 0.23 & & 0.80 & \\
Total & 45 & 11.76 & & & 1 & \\
\hline
\end{tabular}

Significance tests are shown in bold, and ${ }^{\star} 0.01 \leq p<0.05 ;{ }^{*} 0.001 \leq p<0.01$.

Table 1b. Permutational multivariate analysis of variance between fungal community profiles generated by Hinf I. Differences between communities associated with male $(n=23)$ and female $(n=24)$ individuals from three different populations $\left(\mathrm{NH}, 35^{\text {th }}\right.$, UCUT). Values for degrees of freedom (df), sum of squares (SS), mean squares (Mean Sq), F-ratio (F), r-squared $(R 2)$, and $p$-value $(p)$ are displayed. Bold values indicate statistical significance.

\begin{tabular}{lcccccc}
\hline Hinf I & $d f$ & $S S$ & Mean Sq & $F$ & $R 2$ & $p$ \\
\hline Sex & 1 & 0.66 & 0.66 & 3.42 & 0.06 & $\mathbf{0 . 0 0 4}^{\text {** }}$ \\
Population & 2 & 1.33 & 0.66 & 3.43 & 0.12 & $\mathbf{0 . 0 0 1}^{\text {** }}$ \\
Sex x Population & 2 & 0.66 & 0.33 & 1.71 & 0.06 & $\mathbf{0 . 0 4 7}^{\star}$ \\
Residuals & 41 & 7.95 & 0.19 & & 0.74 & \\
Total & 46 & 10.62 & & & 1 & \\
\hline
\end{tabular}

Significance tests are shown in bold, and ${ }^{\star} 0.01 \leq p<0.05 ;{ }^{* *} 0.001 \leq p<0.01$. 
NMDS ordination indicates that this sex-based difference was due primarily to aggregate differences in overall fungal composition rather than high specificity of fungal communities on either sex (Fig. 1a, 2a).

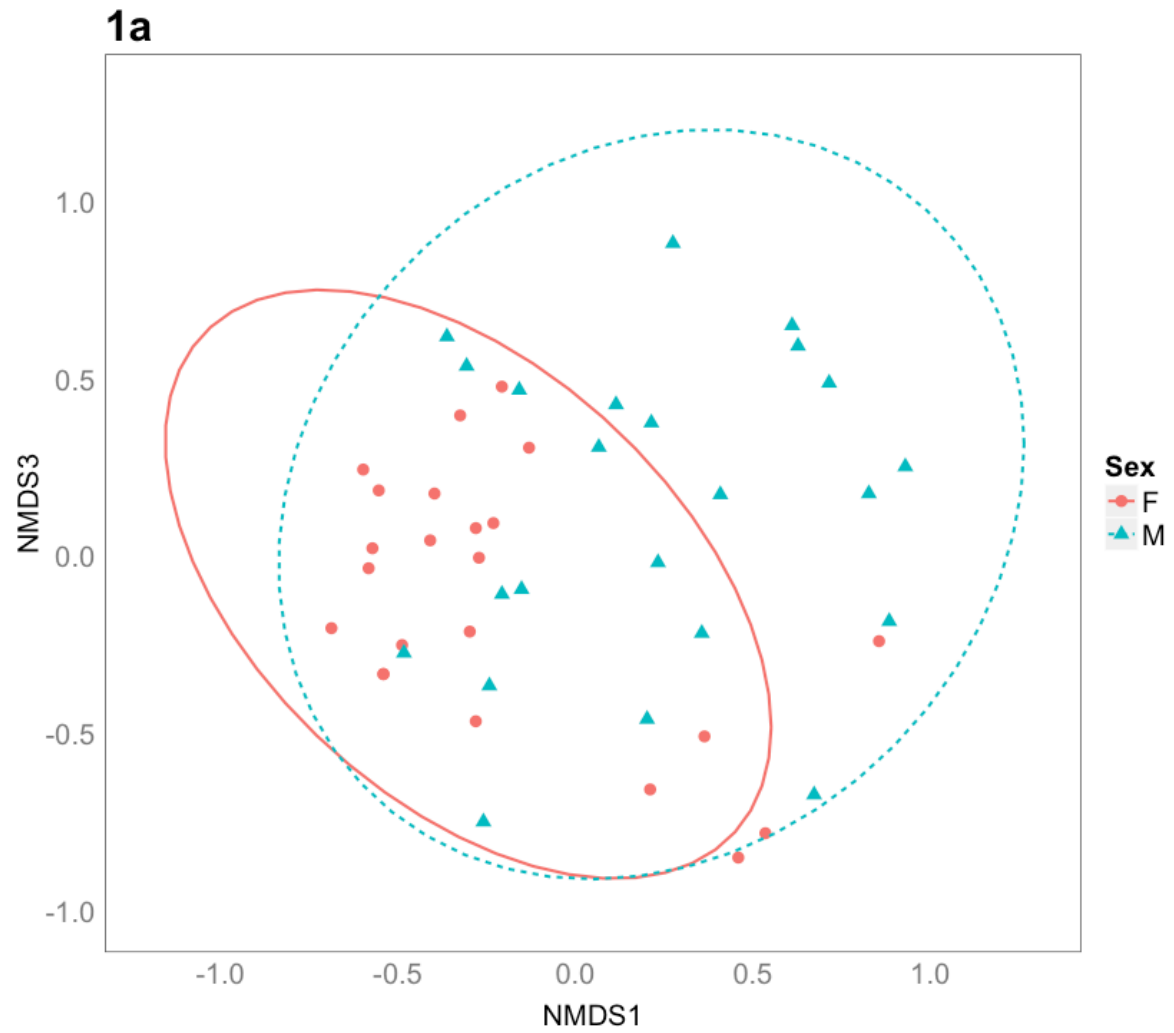

Figure 1a. NMDS ordination of Hae III fungal community profiles by sex (3D Stress $=.16$ ). Fungal communities associated with individuals from all three $C$. purpureus populations examined are represented. Red circles and blue triangles represent female and male associated fungal communities respectively. Solid and dashed line ellipses indicate $95 \%$ confidence intervals for female and male associated communities respectively. 
When ordinations are coded by both sex and C. purpureus populations, the same sex-based pattern is evident across all three populations examined (Fig. 3b, 4b).

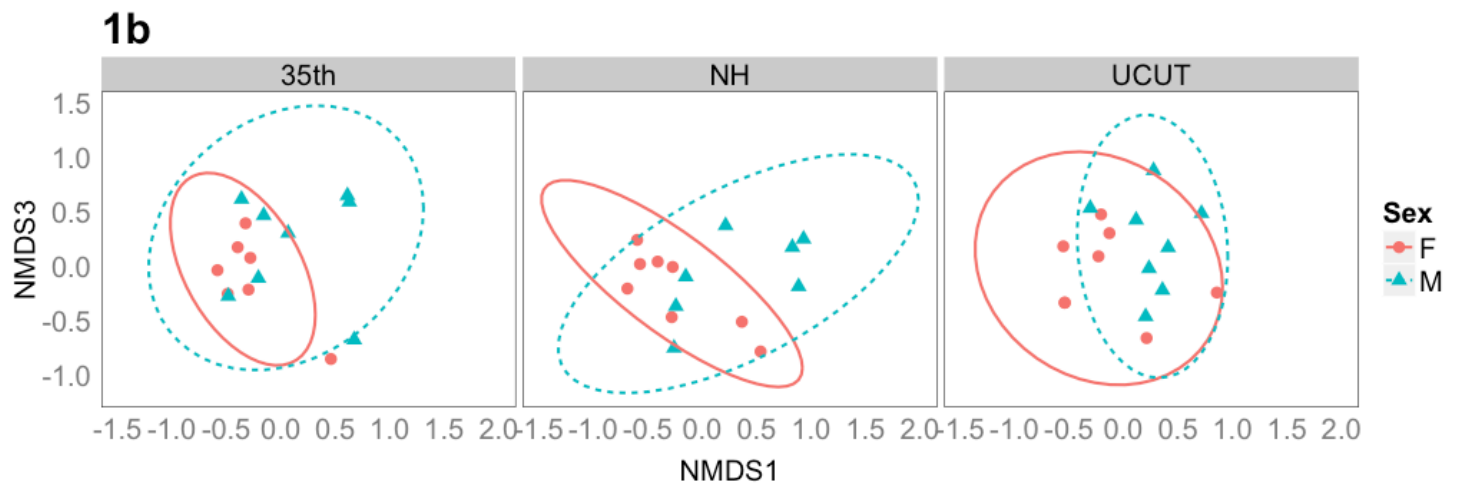

Figure 1b. NMDS ordination of Hae III fungal community profiles by sex and population (3D Stress $=.16$ ). Fungal communities associated with individuals from all three $C$. purpureus populations examined are represented. Circles and triangles represent female and male associated fungal communities respectively. Each of three panels represents fungal communities associated with $C$. purpureus individuals from $35^{\text {th }}, \mathrm{NH}$, and UCUT populations respectively. Solid and dashed line ellipses indicate $95 \%$ confidence intervals for female and male associated communities respectively. 


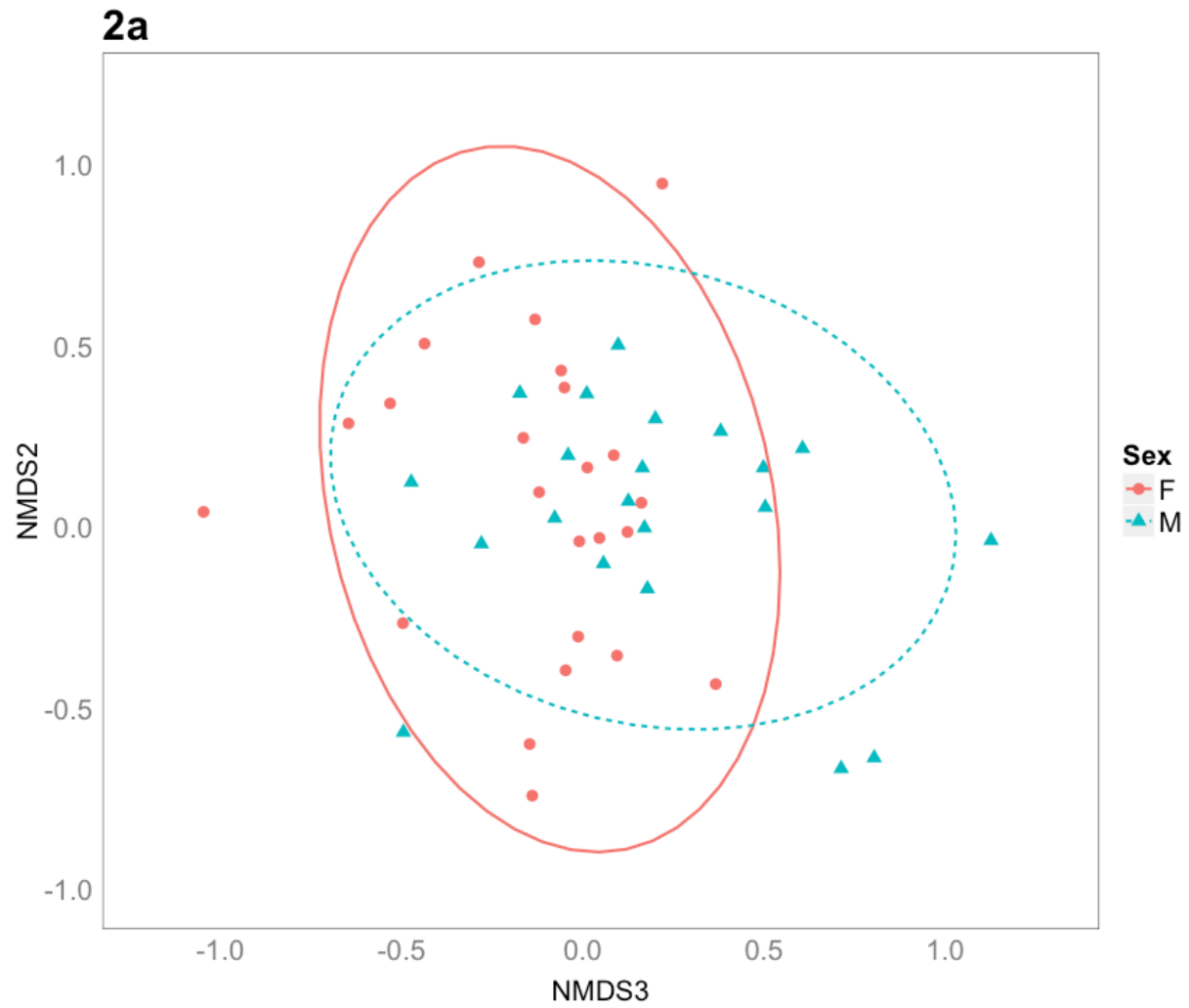

Figure 2a. NMDS ordination of Hinf I fungal community profiles by sex (3D Stress $=.14$ ).

Fungal communities associated with individuals from all three $C$. purpureus populations examined are represented. Red circles and blue triangles represent female and male associated fungal communities respectively. Solid and dashed line ellipses indicate $95 \%$ confidence intervals for female and male associated communities respectively. 


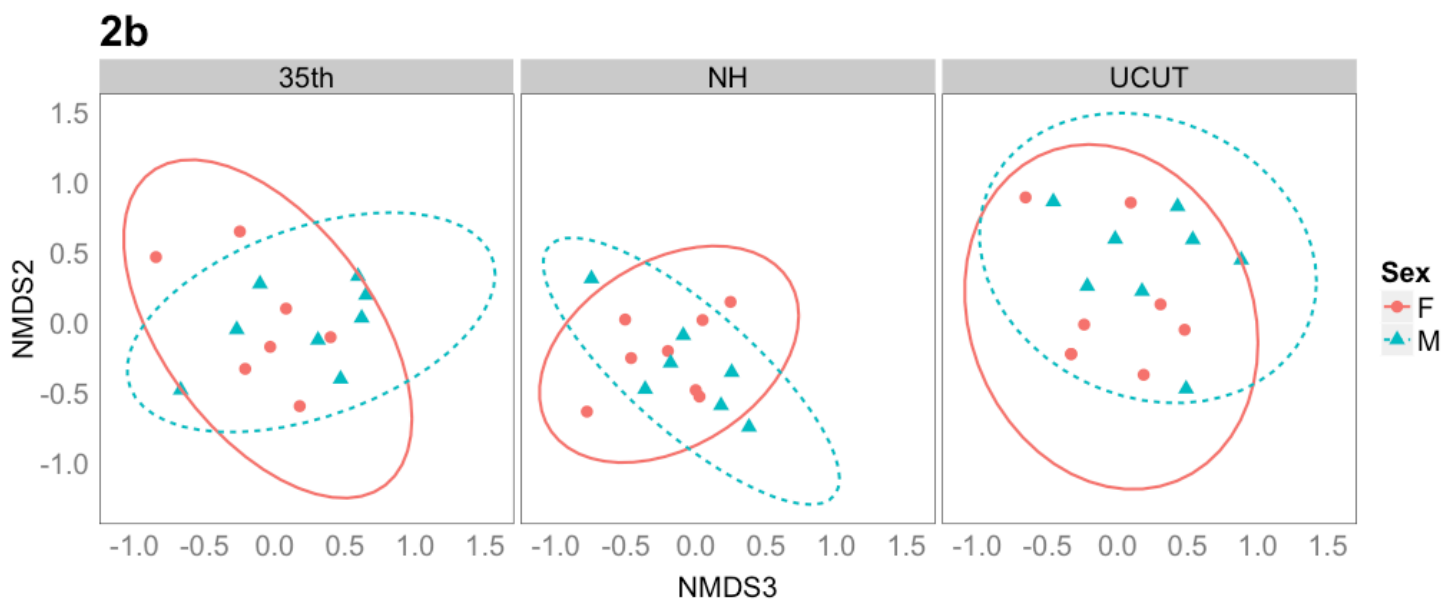

Figure 2b. NMDS ordination of Hinf I fungal community profiles by sex and population (3D Stress $=.14$ ). Fungal communities associated with individuals from all three $C$. purpureus populations examined are represented. Circles and triangles represent female and male associated fungal communities respectively. Each of three panels represents fungal communities associated with $C$. purpureus individuals from $35^{\text {th }}, \mathrm{NH}$, and UCUT populations respectively. Solid and dashed line ellipses indicate $95 \%$ confidence intervals for female and male associated communities respectively. 
Sample-based rarefaction and extrapolation curves for community profiles generated by both enzymes form asymptotes just beyond reference points, indicating that sampling efforts were adequate to accurately capture the diversity of each community without further sampling (Figs. 5a, 6a). Sample completeness curves, which asses the degree of completeness (based on coverage) for a given sampling effort, also form asymptotes close to the reference points indicating that further sampling efforts will not yield a much greater level of sample completeness (Figs. 5b, 6b). Finally, coverage-based rarefaction and extrapolation curves show increased sample coverage with increased sampling effort up to the reference points for each set of community profiles (Figs. 5c, 6c). Since there is only a slight increase in coverage when the reference sample is doubled, as indicated by the sample completeness curves (Figs. 5b, 6b), extrapolated portions of the coverage-based sampling curves are almost invisible signifying that almost no increase in diversity would be expected from further sampling. 
a
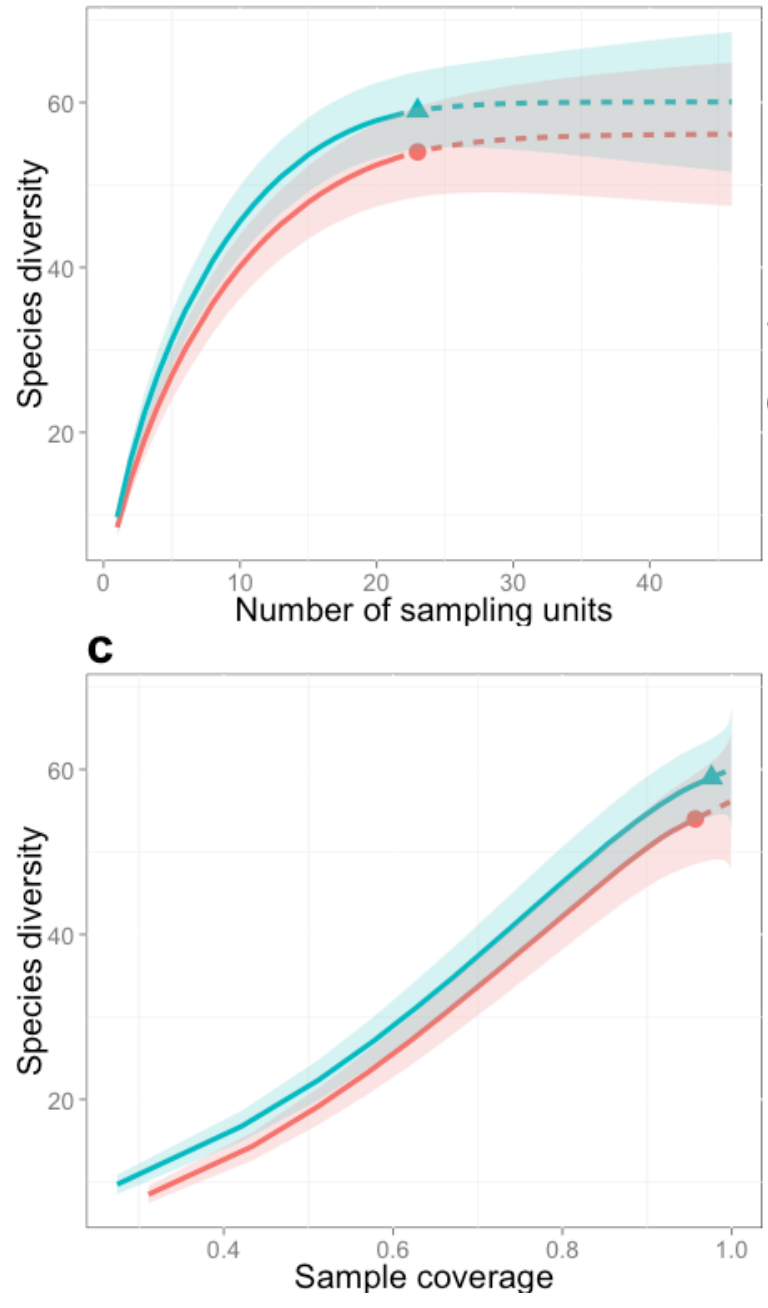

b

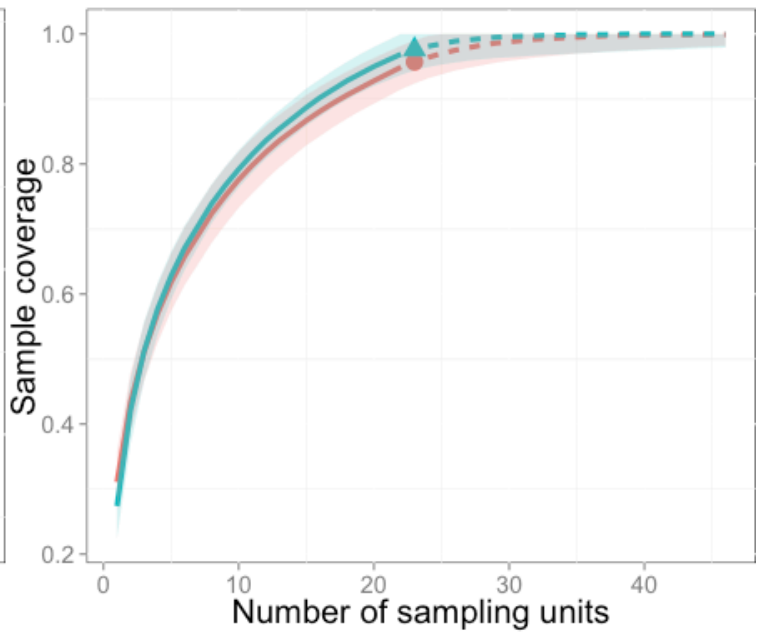

- interpolation - - extrapolation

$F=\mathrm{M}$

Figure 3. Rarefaction and extrapolation curves of fungal community profiles generated by Hae III restriction based T-RFLP. Red and blue elements represent females and males respectively. Solid dots and triangles represent reference samples for females and males respectively. Solid lines indicate interpolated values whereas dashed lines indicate extrapolated values based on Hill numbers $(q=0)$ and extend to double the reference point in panels $a$ and $b$. Shaded areas indicate 95\% confidence interval. (a) Sample-size-based rarefaction and extrapolation sampling curve, (b) sample completeness curve, and (c) coveragebased rarefaction and extrapolation sampling curve. 
a
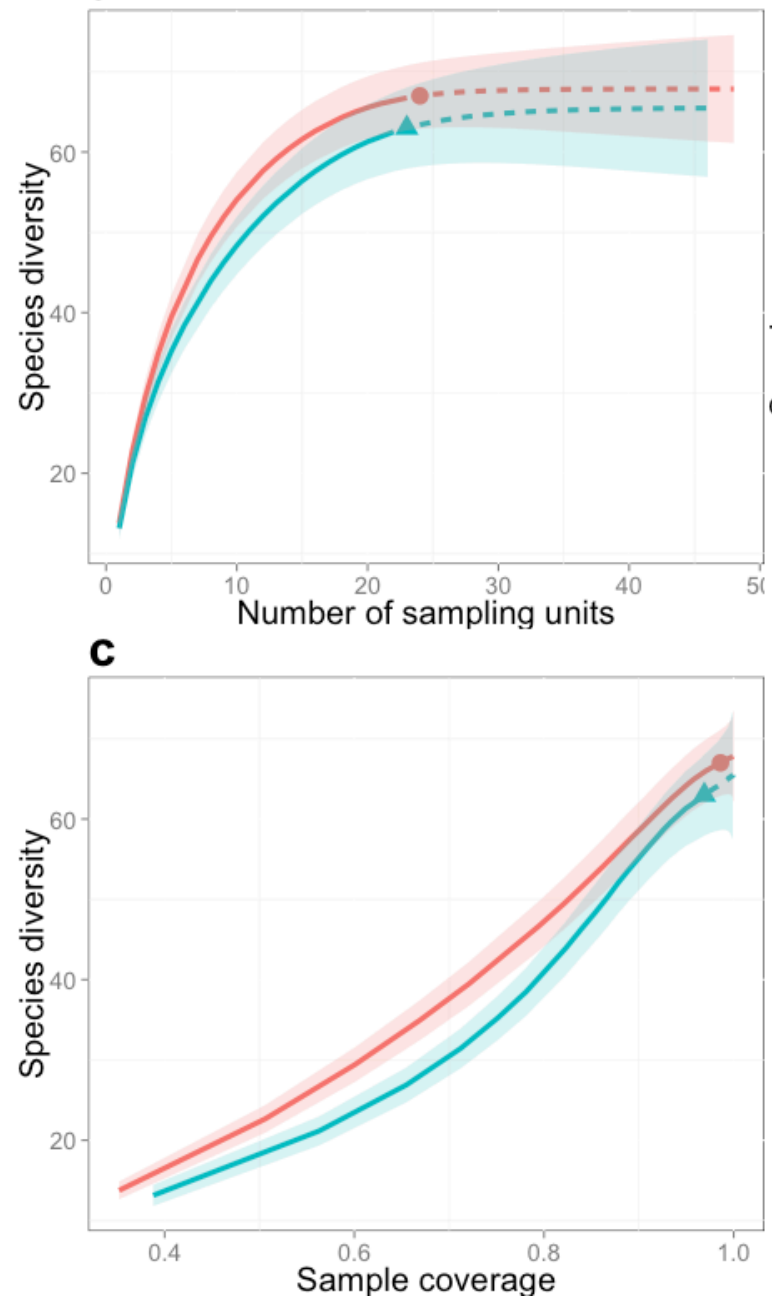

b

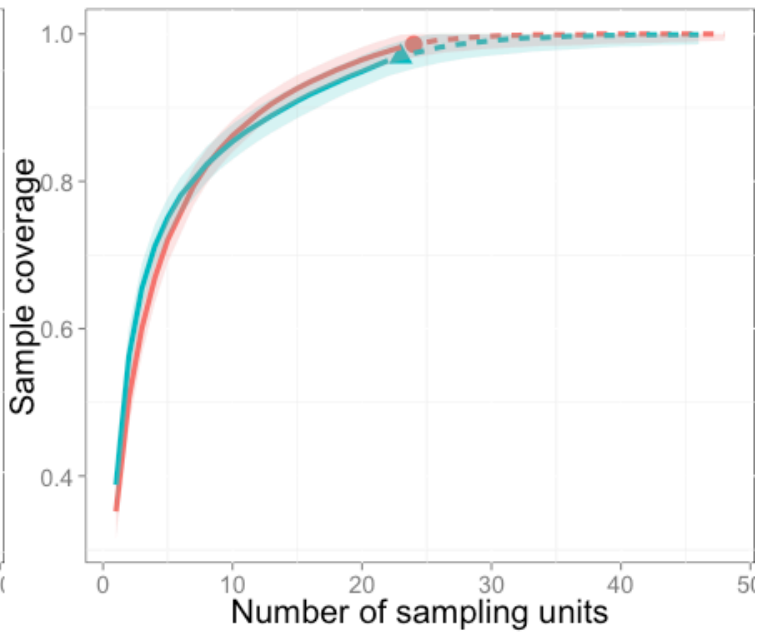

- interpolation - - extrapolation

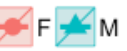

Figure 4. Rarefaction and extrapolation curves of fungal community profiles generated by Hinf I restriction based T-RFLP. Red and blue elements represent females and males respectively. Solid dots and triangles represent reference samples for females and males respectively. Solid lines indicate interpolated values whereas dashed lines indicate extrapolated values based on Hill numbers $(q=0)$ and extend to double the reference point in panels $a$ and $b$. Shaded areas indicate 95\% confidence interval. (a) Sample-size-based rarefaction and extrapolation sampling curve, (b) sample completeness curve, and (c) coveragebased rarefaction and extrapolation sampling curve. 
All non-parametric, asymptotic richness estimates indicate greater OTU richness in male associated fungal communities for profiles generated by both enzymes (Table 2).

Table 2. Non-parametric diversity estimators of fungal diversity. Sample size (n), number of observed OTUs $\left(S_{o b s}\right)$, Mao Tau expected OTU richness $\left(S_{e s t}\right)$, and estimated OTU richness using Chao2 estimator (Chao2) and incidence-based coverage estimator (ICE), \pm standard deviation for fungal community profile generated by Hae III and Hinf I.

\begin{tabular}{lllllll}
\hline Hae III & & $\mathrm{n}$ & $S_{\text {obs }}$ & \multicolumn{1}{c}{$S_{\text {est }}$} & \multicolumn{1}{c}{ Chao2 } & ICE \\
\hline & Females & 23 & 54 & $56.5 \pm 2.18$ & $56.49 \pm 0.0$ & $56.49 \pm 2.5$ \\
& Males & 23 & 59 & $66 \pm 1.37$ & $67.78 \pm 1.6$ & $83.18 \pm 0.0$ \\
\hline Hinf I & & & & & & \\
\hline & Females & 24 & 67 & $65 \pm 2.55$ & $65.01 \pm 0.0$ & $65.01 \pm 2.0$ \\
& Males & 23 & 63 & $78 \pm 1.77$ & $81.07 \pm 2.18$ & $104 \pm 0.0$ \\
\hline
\end{tabular}




\section{Fungal Biomass Estimates}

Overall ergosterol concentrations were statistically significantly greater $(p=0.02 ; \mathrm{df}=1 ; \mathrm{SS}=1.0)$ in male tissues than in female tissues of $C$. purpureus (Fig. 7a, Table 2), a pattern that was consistent across all three populations sampled (Fig. 7b).

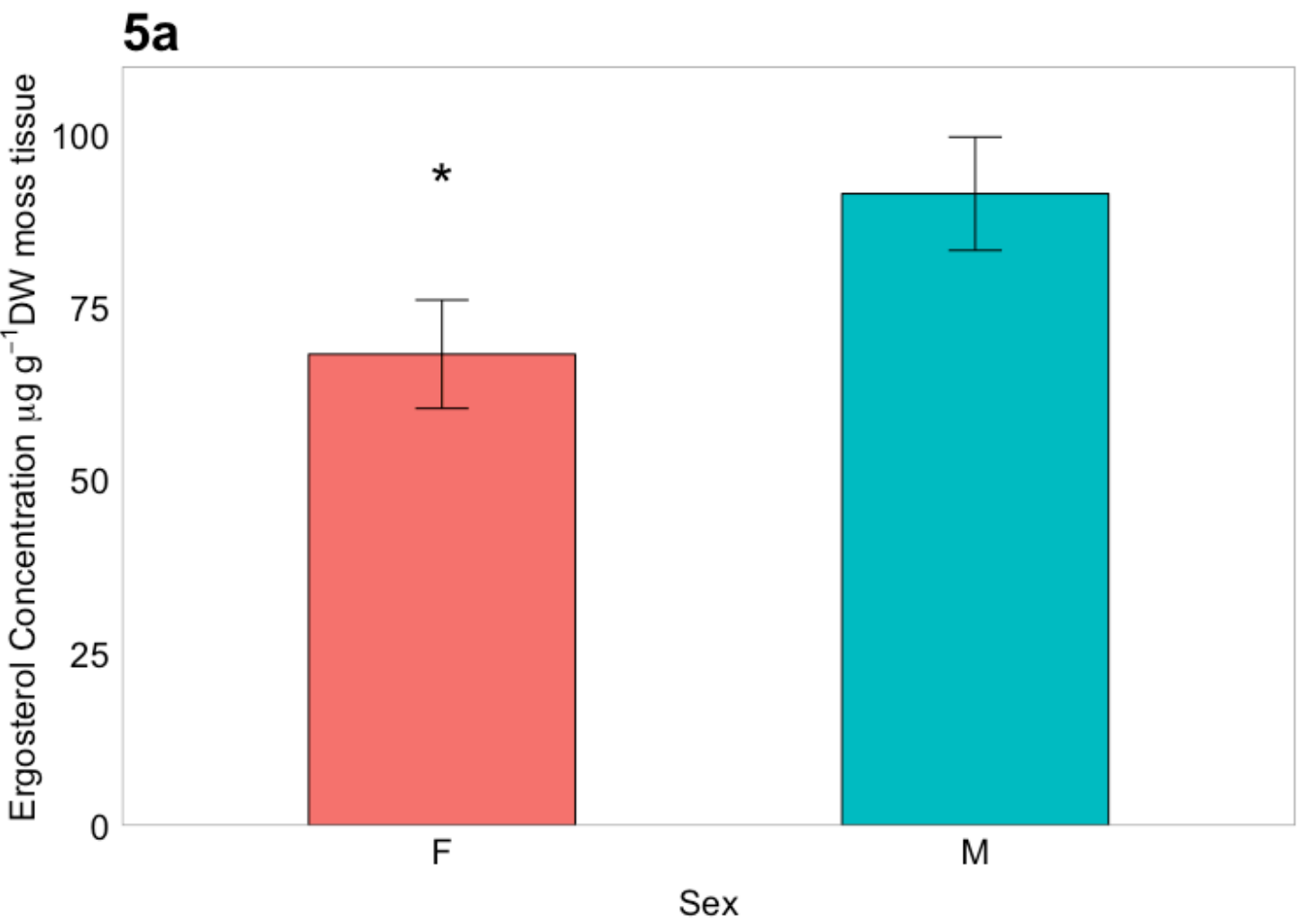

Figure 5a. Ergosterol concentration in tissues of $\boldsymbol{C}$. purpureus by sex. Mean values for all females $(n=22)$ and all males $(n=22)$ are represented by red and blue bars respectively. Error bars indicate \pm standard error. Ergosterol concentration in male and female moss tissues was statistically significantly different $(p=0.02 ; \mathrm{df}=1 ; \mathrm{SS}=1.0)$. 


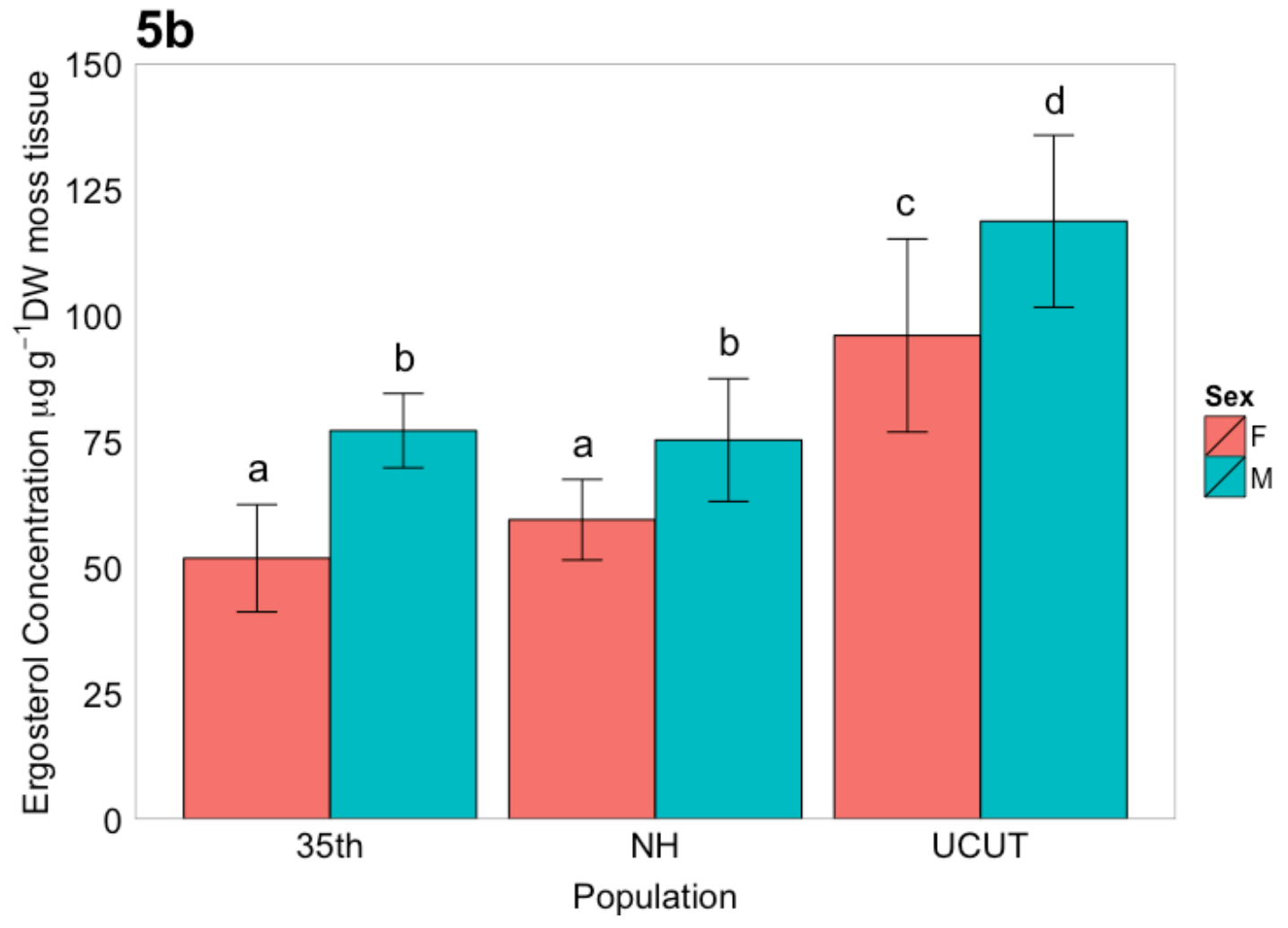

Figure 5b. Ergosterol concentration in tissues of $C$. purpureus by sex and population. Mean values for females $(n=22)$ and males $(n=22)$ within each of three populations $\left(35^{\text {th }}, \mathrm{NH}\right.$, and UCUT) are represented by red and blue bars respectively. Error bars indicate \pm standard error. Populations that do not share letters are statistically significantly different from one another $(p<0.001)$. Overall ergosterol concentration in male and female moss tissues across populations was statistically significantly different $(p=0.003 ; d f=2 ; S S=2.44)$. 
Populations also differed in overall ergosterol concentrations $(p=0.003$;

$\mathrm{df}=2$; $\mathrm{SS}=2.44$ ), with individuals from the UCUT population having statistically significantly higher levels than individuals in either the 35th or $\mathrm{NH}$ populations

(Fig. 7b, Table 4). The interaction between plant sex and population was not statistically significant $(\mathrm{p}=0.6 ; \mathrm{df}=2 ; \mathrm{SS}=0.18)$.

Table 3. Results of two-way ANOVA for ergosterol concentration in moss tissues as influenced by host sex (male and female) and population ( $\mathrm{NH}, 35^{\text {th }}$, and UCUT). Values for degrees of freedom (df), sum of squares (SS), mean squares (Mean Sq), F-ratio (F), and p-value (p) are displayed. Bold values indicate statistical significance.

\begin{tabular}{|c|c|c|c|c|c|}
\hline & $d f$ & SS & Mean $S q$ & $F$ & $p$ \\
\hline Population & 2 & 2.44 & 1.22 & 6.80 & $0.003^{\star \star}$ \\
\hline Sex & 1 & 1.00 & 1.00 & 5.59 & $0.023^{*}$ \\
\hline Sex x Population & 2 & 0.18 & 0.09 & 0.50 & 0.613 \\
\hline Residuals & 38 & 6.82 & 0.18 & & \\
\hline
\end{tabular}

Table 4. Results of post-hoc Tukey HSD test showing pairwise differences in mean ergosterol concentration between populations ( $\mathrm{NH}, 35^{\text {th }}$, and UCUT). Differences between means (Difference), lower (Lower) and upper (Upper) bounds of confidence, and p-value after adjustment for multiple comparisons ( $p$ adj) are displayed. Bold values indicate significant differences between means.

\begin{tabular}{lcccc}
\hline & Difference & Lower & Upper & p adj \\
\hline NH-35 $^{\text {th }}$ & 0.10 & -0.28 & 0.48 & 0.792 \\
UCUT-35 $^{\text {th }}$ & 0.54 & 0.15 & 0.92 & $\mathbf{0 . 0 0 3}^{\star \star}$ \\
UCUT-NH $^{\text {** }}$ & 0.43 & 0.06 & 0.81 & $\mathbf{0 . 0 1 9}^{\text {* }}$ \\
\hline
\end{tabular}

Significance tests are shown in bold, and ${ }^{*} 0.01 \leq p<0.05 ;{ }^{* *} 0.001 \leq p<0.01$. 


\section{Chapter 4: Discussion}

The goal of the present study was to investigate how moss sex influences associated fungal community composition and biomass under common garden conditions. I used a rapid and robust molecular fingerprinting method (T-RFLP) that boasts high accuracy in assessing microbial community structure (Pilloni et al., 2012), but is limited by its inability to resolve species identity. My results show evidence of host sex-specific structuring of fungal community composition associated with the moss $C$. purpureus (Figs. 3a, 3b). Differences in fungal composition across the three C. purpureus populations examined were also evident (Figs. 3b, 4b), though sex-specific patterns were maintained and female associated fungal communities generally appear to be more similar to one another as evidenced by tighter clustering relative to male associated communities in NMDS ordinations. Diversity metrics generated using all three non-parametric, asymptotic species richness estimators (Mao Tau, Chao2, ICE) indicate greater overall species richness in male associated fungal communities.

Furthermore, I observed significantly greater amounts of fungal biomass associated with the tissues of male individuals than females, suggesting that host sex is an important factor influencing the extent of fungal abundance. The quantities of ergosterol measured in greenhouse populations of $C$. purpureus were comparable $($ mean female $=69.3$, mean male $=91.5$, mean total $=79.9 \mu \mathrm{g}$ ergosterol $\mathrm{g}^{-1}$ dry weight plant material) to those previously measured in forest 
mosses (48.5 $\mu \mathrm{g}$ ergosterol $\mathrm{g}^{-1}$ dry weight plant material; Davey et al., 2009), which indicates that fungal loads can be just as high (and higher in this study) in mosses that prefer disturbed habitats such as $C$. purpureus, and likewise under greenhouse conditions. I realize that although the synthetic nature of common garden approaches may not accurately reflect the ecological dynamics in natural populations, they are an indispensible tool for examining genetically rooted features of populations under controlled environmental conditions.

Mosses are considered foundation species owing to their disproportionately large influence on ecosystem processes and community structure in the biomes they inhabit (Lindo \& Gonzalez, 2010; Turetsky et al., 2012). A number of the critical ecological roles of mosses are manifestations of their intimate relationships with other organisms, for example, the symbiotic association of dinitrogen-fixing cyanobacteria with feather mosses (Turetsky, 2003; Lindo \& Gonzalez, 2010). The sheer magnitude of the fungal presence generally observed within the bryosphere is indicative, at the very least, of a major source of fungal propagules (Davey \& Currah, 2006), but undoubtedly extends functional importance at the ecosystem level (Christensen, 1989), similar to other moss-associated biota. The separation of sexes is an ancient reproductive strategy that has emerged many times in the bryophytes across evolutionary time (McDaniel et al., 2011). Sexual dimorphisms are widespread in dioicous bryophytes (Fuselier \& Stark, 2004) and are the basis of differential fitness optima for each sex. Females are almost always larger in size (Shaw \& 
Beer, 1999; Glime \& Bisang, 2014a) which is likely a consequence of the resources required by the maternal gametophyte to provide sole sustenance to the maturing sporophyte. Female sex structures (archegonia) typically initiate later and develop faster than male structures (antheridia), which also appear to have a narrower range of environmental conditions in which they are expressed (Stark, 2002; Glime \& Bisang, 2014b). The unique life history and physiological traits of the sexes create distinct physical niches that are expected to be suitable for different fungal taxa accordingly. Davey et al. (2012a) observed significant seasonal differences in fungal community composition associated with three common boreal mosses, all of which are dioicous, though host moss sex was not considered in their study.

Recent work measuring leaf, cell, and physiological traits in C. purpureus from the same populations used in this study revealed that there were significant sex-specific differences in characteristics such as leaf thickness, canopy mass area, and photosynthetic capacity, among others. (Slate et al. unpublished). Interestingly females had larger, thicker leaves with thicker cell walls than males that may provide greater protection from invading fungi who often inhabit specific microniches within the cells of the host moss (Döbbeler, 2002; Ptaszyńska et al., 2009); perhaps explaining to some extent the reduced fungal richness and biomass associated with female individuals of $C$. purpureus observed in the current study. Slate et al. also found that females had significantly greater darkadapted $F_{v} / F_{m}$ values which is indicative of the maximum potential quantum 
efficiency of Photosystem II (i.e. photosynthetic performance) (Maxwell \& Johnson, 2000), which coupled with other leaf traits that likely enhance $\mathrm{CO}_{2}$ assimilation in females compared to males, may allow for greater net assimilation by females. If this is the case, then females may have a greater resource pool to invest in other traits such as chemical defenses. Better-defended females are common among dioecious angiosperms (Jing \& Coley, 1990; Fritz \& Simms, 1992; Ågren et al., 1999; Cornelissen \& Stiling, 2005; Cepeda-Cornejo \& Dirzo, 2010; Barrett \& Hough, 2013) and may also explain the more refined fungal communities and lower fungal biomass observed in female individuals of $C$. purpureus.

Another factor that likely contributes to sex-specific patterns in fungal affiliations is resource availability associated with sexual expression. Stark (2002) highlights the different lines of evidence that suggest that male antheridia are more energetically expensive to produce than female archegonia. This is further supported by the findings of McDaniel (2005) who showed that there is a tradeoff between allocation to reproductive and vegetative tissue in $C$. purpureus males, but not in females. A greater physiological investment to male sexual structures, such as lipid and starch rich sperm (Paolillo, 1979; Renzaglia \& Garbary, 2001) and mucilage exuded by paraphyses (Harvey-Gibson \& MillerBrown, 1927) and may provide a richer storehouse of resources for fungi to exploit, which may in turn explain the significantly greater fungal biomass and richness associated with male tissues in this study. These components have 
been observed to serve as attractants and food for arthropods (Harvey-Gibson \& Miller-Brown, 1927) supporting the possibility of them being a food source for microbiota as well. Likewise, the chemical properties of female sexual structures may also influence the distribution of fungi in the moss phyllosphere. Early work by Pfeffer (1884) and later Kaiser et al. (1985) demonstrated that moss archegonia produce sugars (namely sucrose) that were shown to attract chemotactic male sperm (Cronberg, 2012). Subsequent investigations revealed that a suite of sugars accumulate in specialized cells of the archegonia during the development of Bryum capillare, and are released shortly before fertilization creating a gradient that sperm can follow (Kaiser et al., 1985). Such accretion of sugars may be an important factor effecting the composition of microbial inhabitants as observed in the floral nectar of vascular plants (Álvarez-Pérez \& Herrera, 2013). However, owing to the actually low relative concentration of sucrose $(0.086 \%$; Ziegler et al., 1988$)$ in archegonia exudates compared to nectar found in angiosperm flowers (7-70\%; Nicolson et al., 2007; Cronberg, 2012), perhaps a more qualitative (i.e. specific community composition) rather than quantitative (i.e. species abundance) effect on microbial communities might be excepted. The overall greater richness together with the greater dissimilarity of community composition exhibited by male associated fungal communities relative to female communities; may be indicative of a more specific assembly or narrower realized niche for fungi associated with females. 
The potential for multi-trophic community feedbacks associated with genetic variation in foundation species has been previously demonstrated in various angiosperm systems (see review by Whitham et al., 2006), and was recently shown to be driven by plant sex (Petry et al., 2013). In their study, Petry and collaborators found that female plants of the species Valeriana edulis attracted a disproportionate abundance of aphid, aphid predators, and aphidtending ants, showing 4-fold, 1.5-fold, and 4-fold higher densities respectively compared to their male counterparts. Interestingly, differences in floral nectar between males and females were found in large part to explain the sexual dimorphisms in arthropod communities observed. This finding suggests that a resource-based partitioning of community structure across sexes is indeed a strong possibility as I have speculated for $C$. purpureus, though instead with a male bias. Other studies have also observed sex-specific biotic interactions with between plants and fungi. In a study by Eppley et al. (2009), higher levels of colonization (1.62-2.58 times greater) by arbuscular mycorhizal fungi were observed in the roots of females versus males of the dioecious grass Distichlis spicata under field conditions. The authors suggest that these observed differences may cause antagonisms between males and females through intersexual competition for resources. Though the functional capacities of the fungal communities examined in my study remain to be resolved, the likelihood of some level of sexual antagonism or possibly synergism (see below) based on fungal interactions remains. Given that such complex communities are also 
common in the bryosphere, I predict that similar differential structuring is likely occurring as a result of moss sexual identity. In a recent study, Rosenstiel et al. (2013) found that Collembolan microarthropods commonly occurring in the $C$. purpureus phyllosphere were differentially attracted to complex VOC profiles emitted from wild-collected female gametophytic tissue. As the VOCs originating from moss tissues were not distinguished from those emitted from phyllosphere microbes, it is possible that specific fungal volatiles may be functioning as attractants for the largely fungivorous microarthropods.

The milieu of sexually dimorphic traits exhibited by dioicous bryophytes provides a robust foundation for divergent structuring of resident fungal communities, but further work is necessary to link the complex physiological and phenological events that define them and their population and community level effects. This work provides a first glance at how genetically based sexual systems in early land plants influence affiliated fungal composition.

\section{Future Directions}

While this research takes initial steps towards understanding sex-specific structuring of community phenotypes in a moss based system, there is a fruitful path ahead for further work in this area. Utilizing next-generation sequencing techniques will allow for the identification of microbial elements, and coupled with phylogenetic methods, can greatly strengthen our knowledge concerning the evolutionary trajectories that build community interactions. In the same vein, 
including other moss species featuring dioicous and other sexual systems in such studies will reveal the extent to which sex-specific community structuring exists in this group. Furthermore, identifying and incorporating quantitative trait loci that govern moss sex-specific characteristics influential across community levels (e.g. concentration of phenolics in tissues, generation of nutritive exudates) will open the door to testing for the relative strength of continuous traits at different levels of expression, as well as their heritability across generations. Such techniques have been applied to the study of community genetics in the Populus model system (Shuster et al., 2006; Whitham et al., 2006) and no doubt are applicable to moss systems with recently available genomic resources for Physcomitrella patens and C. purpureus. 


\section{References}

Adams DG, Duggan PS. 2008. Cyanobacteria-bryophyte symbioses. Journal of Experimental Botany 59: 1047-1058.

Ågren J, Danell K, Elmqvist T, Ericson L, Hjältén J. 1999. Sexual Dimorphism and Biotic Interactions. In: Geber PDMA, Dawson PDTE, Delph PDLF, eds. Gender and Sexual Dimorphism in Flowering Plants. Springer Berlin Heidelberg, 217-246.

Algarra P, Linder S, Thümmler F. 1993. Biochemical evidence that phytochrome of the moss Ceratodon purpureus is a light-regulated protein kinase. FEBS Letters 315: 69-73.

Álvarez-Pérez S, Herrera CM. 2013. Composition, richness and nonrandom assembly of culturable bacterial-microfungal communities in floral nectar of Mediterranean plants. FEMS Microbiology Ecology 83: 685-699.

Angelini C, Altieri AH, Silliman BR, Bertness MD. 2011. Interactions among Foundation Species and Their Consequences for Community Organization, Biodiversity, and Conservation. BioScience 61: 782-789.

Arróniz-Crespo M, Pérez-Ortega S, De los Ríos A, Green TGA, Ochoa-Hueso R, Casermeiro MÁ, de la Cruz MT, Pintado A, Palacios D, Rozzi R, et al. 2014. Bryophyte-Cyanobacteria Associations during Primary Succession in Recently Deglaciated Areas of Tierra del Fuego (Chile). PLoS ONE 9: e96081.

Bachtrog D, Kirkpatrick M, Mank JE, McDaniel SF, Pires JC, Rice W, Valenzuela N. 2011. Are all sex chromosomes created equal? TRENDS in Genetics 27: 350-357.

Bailey JK, Deckert R, Schweitzer JA, Rehill BJ, Lindroth RL, Gehring C, Whitham TG. 2005. Host plant genetics affect hidden ecological players: links among Populus, condensed tannins, and fungal endophyte infection. Canadian Journal of Botany 83: 356-361.

Bangert RK, Lonsdorf EV, Wimp GM, Shuster SM, Fischer D, Schweitzer JA, Allan GJ, Bailey JK, Whitham TG. 2006. Genetic structure of a foundation species: scaling community phenotypes from the individual to the region. Heredity 100: 121-131.

Barrett SCH, Hough J. 2013. Sexual dimorphism in flowering plants. Journal of experimental botany 64: 67-82.

Baumeister D, Callaway RM. 2006. Facilitation by pinus flexilis during succession: a hierarchy of mechanisms benefits other plant species. Ecology 87: 1816-1830. 
Bierzychudek P, Eckhart V. 1988. Spatial Segregation of the Sexes of Dioecious Plants.pdf. The American Naturalist 132: 34-43.

Blackwood CB, Hudleston D, Zak DR, Buyer JS. 2007. Interpreting Ecological Diversity Indices Applied to Terminal Restriction Fragment Length Polymorphism Data: Insights from Simulated Microbial Communities. Applied and Environmental Microbiology 73: 5276-5283.

Blok D, Heijmans MMPD, Schaepman-Strub G, Ruijven J van, Parmentier FJW, Maximov TC, Berendse F. 2011. The Cooling Capacity of Mosses: Controls on Water and Energy Fluxes in a Siberian Tundra Site. Ecosystems 14: 1055-1065.

Brändle M, Brandl R. 2006. Is the composition of phytophagous insects and parasitic fungi among trees predictable? Oikos 113: 296-304.

Bray JR, Curtis JT. 1957. An Ordination of the Upland Forest Communities of Southern Wisconsin. Ecological Monographs 27: 325-349.

Cepeda-Cornejo V, Dirzo R. 2010. Sex-related differences in reproductive allocation, growth, defense and herbivory in three dioecious neotropical palms. PloS One 5: e9824.

Chao A. 1987. Estimating the Population Size for Capture-Recapture Data with Unequal Catchability. Biometrics 43: 783-791.

Chao A, Gotelli NJ, Hsieh TC, Sander EL, Ma KH, Colwell RK, Ellison AM. 2014. Rarefaction and extrapolation with Hill numbers: a framework for sampling and estimation in species diversity studies. Ecological Monographs 84: 45-67.

Chapin III FS, Oechel WC, Van Cleve K, Lawrence W. 1987. The role of mosses in the phosphorus cycling of an Alaskan black spruce forest. Oecologia 74: 310-315.

Christensen M. 1989. A View of Fungal Ecology.pdf. Mycologia 81: 1-19.

Clarke LJ, Robinson SA. 2008. Cell wall-bound ultraviolet-screening compounds explain the high ultraviolet tolerance of the Antarctic moss, Ceratodon purpureus. New Phytologist 179: 776-783.

Colwell RK. 2013. EstimateS: Statistical estimation of species richness and shared species from samples. Version 9 and earlier. User's Guide and application. viceroy. eeb. uconn. edu/estimates/index. html.

Colwell RK, Mao CX, Chang J. 2004. Interpolating, extrapolating, and comparing incidence-based species accumulation curves. Ecology 85: 2717-2727. 
Cornelissen JH, Lang SI, Soudzilovskaia NA, During HJ. 2007. Comparative cryptogam ecology: a review of bryophyte and lichen traits that drive biogeochemistry. Annals of Botany 99: 987-1001.

Cornelissen T, Stiling P. 2005. Sex-biased herbivory: a meta-analysis of the effects of gender on plant-herbivore interactions. Oikos 111: 488-500.

Cronberg N. 2012. Animal-mediated fertilization in bryophytes-parallel or precursor to insect pollination in angiosperms? Lindbergia 35: 76-85.

Culman SW, Gauch HG, Blackwood CB, Thies JE. 2008. Analysis of T-RFLP data using analysis of variance and ordination methods: a comparative study. Journal of microbiological methods 75: 55-63.

Dahlman L, Zetherström M, Sundberg B, Näsholm T, Palmqvist K. 2002. Measuring Ergosterol and Chitin in Lichens. In: Kranner DIC, Beckett PDRP, Varma PDAK, eds. Springer Lab Manuals. Protocols in Lichenology. Springer Berlin Heidelberg, 348-362.

Damman AWH. 1986. Hydrology, development, and biogeochemistry of ombrogenous peat bogs with special reference to nutrient relocation in a western Newfoundland bog. Canadian Journal of Botany 64: 384-394.

Darwin C. 1871. The descent of man and selection in relation to sex. London: J. Murray.

Davey ML, Currah RS. 2006. Interactions between mosses (Bryophyta) and fungi. Canadian Journal of Botany 84: 1509-1519.

Davey ML, Heegaard E, Halvorsen R, Kauserud H, Ohlson M. 2012a. Ampliconpyrosequencing-based detection of compositional shifts in bryophyte-associated fungal communities along an elevation gradient. Molecular Ecology: n/a-n/a.

Davey ML, Heegaard E, Halvorsen R, Ohlson M, Kauserud H. 2012b. Seasonal trends in the biomass and structure of bryophyte-associated fungal communities explored by 454 pyrosequencing. New Phytologist.

Davey ML, Nybakken L, Kauserud H, Ohlson M. 2009. Fungal biomass associated with the phyllosphere of bryophytes and vascular plants. Mycological Research 113: 1254-1260.

DeLucia EH, Turnbull MH, Walcroft AS, Griffin KL, Tissue DT, Glenny D, McSeveny TM, Whitehead D. 2003. The contribution of bryophytes to the carbon exchange for a temperate rainforest. Global Change Biology 9: 1158-1170. 
Desirò A, Duckett JG, Pressel S, Villarreal JC, Bidartondo MI. 2013. Fungal symbioses in hornworts: a chequered history. Proceedings of the Royal Society of London B: Biological Sciences 280: 20130207.

Diamond JM. 1975. Assembly of species communities. In: M.L. Cody, J.M. Diamond, eds. Ecology and Evolution of Communities. Massachusetts: Harvard Univesity Press, 342-444.

Diaz S, Cabido M, Casanoves F. 1998. Plant functional traits and environmental filters at a regional scale. Journal of Vegetation Science 9: 113-122.

Döbbeler P. 2002. Microniches occupied by bryophilous ascomycetes. Nova Hedwigia 75: 275-306.

Döbbeler P, Hertel H. 2013. Bryophilous ascomycetes everywhere: Distribution maps of selected species on liverworts, mosses and Polytrichaceae*. Herzogia 26: 361-404.

Dunfield P, knowles R, Dumont R, Moore TR. 1993. Methane production and consumption in temperate and subarctic peat soils: Response to temperature and pH. Soil Biology and Biochemistry 25: 321-326.

Dungey HS, Potts BM, Whitham TG, Li H-F. 2000. Plant genetics affects arthropod community richness and composition: evidence from a synthetic eucalypt hybrid population. Evolution 54: 1938-1946.

Ellison AM, Bank MS, Clinton BD, Colburn EA, Elliott K, Ford CR, Foster DR, Kloeppel BD, Knoepp JD, Lovett GM, et al. 2005. Loss of foundation species: consequences for the structure and dynamics of forested ecosystems. Frontiers in Ecology and the Environment 3: 479-486.

Eppley SM, Mercer CA, Haaning C, Graves CB. 2009. Sex-specific variation in the interaction between Distichlis spicata (Poaceae) and mycorrhizal fungi. American Journal of Botany 96: 1967-1973.

Felix H. 1988. Fungi on bryophytes, a review. Botanica Helvetica 98: 239-269.

Fritz RS, Simms EL. 1992. Plant Resistance to Herbivores and Pathogens: Ecology, Evolution, and Genetics. University of Chicago Press.

Fuselier L, Stark LR. 2004. Sexual dimorphism in bryophytes: patterns and consequences. Sexual dimorphism in bryophytes: patterns and consequences. Salt Lake City, Utah, . 
Glime JM, Bisang I. 2014a. Chapter 3-3 Sexuality: Size and Sex Differences. Bryophyte Ecology. Michigan Technological University and the International Association of Bryologists., .

Glime JM, Bisang I. 2014b. Chapter 3-2 Sexuality: Sex Ratio and Sex Expression. Bryophyte Ecology. Michigan Technological University and the International Association of Bryologists, .

Gorham E. 1991. Northern Peatlands: Role in the Carbon Cycle and Probable Responses to Climatic Warming. Ecological Applications 1: 182-195.

Gornall JL, Jónsdóttir IS, Woodin SJ, Van der Wal R. 2007. Arctic mosses govern below-ground environment and ecosystem processes. Oecologia 153: 931-941.

Harvey-Gibson RJ, Miller-Brown D. 1927. Fertilization of Bryophyta. : 190-191.

Herzog TCJ. 1926. Geographie der Moose. Gustav Fischer.

Hochwender CG, Fritz RS. 2004. Plant genetic differences influence herbivore community structure: evidence from a hybrid willow system. Oecologia 138: 547557.

Horsley K, Stark LR, McLetchie DN. 2011. Does the silver moss Bryum argenteum exhibit sex-specific patterns in vegetative growth rate, asexual fitness or prezygotic reproductive investment? Annals of Botany 107: 897-907.

Jing SW, Coley PD. 1990. Dioecy and Herbivory: The Effect of Growth Rate on Plant Defense in Acer Negundo. Oikos 58: 369-377.

Johnson MTJ, Agrawal AA. 2005. Plant genotype and environment interact to shape a diverse arthropod community on evening primrose (oenothera biennis). Ecology 86: 874-885.

Johnson MTJ, Stinchcombe JR. 2007. An emerging synthesis between community ecology and evolutionary biology. Trends in Ecology \& Evolution 22: 250-257.

Jules ES, Shaw AJ. 1994. Adaptation to Metal-Contaminated Soils in Populations of the Moss, Ceratodon purpureus: Vegetative Growth and Reproductive Expression. American Journal of Botany 81: 791-797.

Kaiser K, Outlaw WH, Ziegler H. 1985. Sucrose content of receptive archegonia of the moss Bryum capillare Hedw. Naturwissenschaften: 378-379.

Kang H, Freeman C, W. Ashendon T. 2001. Effects of elevated CO2 on fen peat biogeochemistry. Science of The Total Environment 279: 45-50. 
Kauserud HKH, Mathiesen CMC, Ohlson MOM. 2008. High diversity of fungi associated with living parts of boreal forest bryophytes. Botany 86: 1326-1333.

Keddy PA. 1992. Assembly and response rules: two goals for predictive community ecology. Journal of Vegetation Science 3: 157-164.

Kelt DA, Taper ML, Meserve PL. 1995. Assessing the Impact of Competition on Community Assembly: A Case Study using Small Mammals. Ecology 76: 1283-1296.

Kenrick P, Crane PR. 1997. The origin and early evolution of plants on land. Nature 389: 33-39.

Kohn G, Hartmann E, Stymne S, Beutelmann P. 1994. Biosynthesis of Acetylenic Fatty Acids in the Moss Ceratodon purpureus (Hedw.) Brid. Journal of Plant Physiology 144: 265-271.

Kunstler G, Lavergne S, Courbaud B, Thuiller W, Vieilledent G, Zimmermann NE, Kattge J, Coomes DA. 2012. Competitive interactions between forest trees are driven by species' trait hierarchy, not phylogenetic or functional similarity: implications for forest community assembly. Ecology Letters 15: 831-840.

Lailvaux SP, Vincent SE. 2007. Ecological dimorphisms: An introduction to the symposium. Integrative and Comparative Biology 47: 169-171.

Lee S-M, Chao A. 1994. Estimating Population Size Via Sample Coverage for Closed Capture-Recapture Models. Biometrics 50: 88.

Lenton TM, Crouch M, Johnson M, Pires N, Dolan L. 2012. First plants cooled the Ordovician. Nature Geoscience 5: 86-89.

Ligrone R, Carafa A, Lumini E, Bianciotto V, Bonfante P, Duckett JG. 2007. Glomeromycotean associations in liverworts: a molecular, cellular, and taxonomic analysis. American Journal of Botany 94: 1756-1777.

Lindo Z, Gonzalez A. 2010. The bryosphere: an integral and influential component of the Earth's biosphere. Ecosystems 13: 612-627.

Lindo Z, Nilsson M-C, Gundale MJ. 2013. Bryophyte-cyanobacteria associations as regulators of the northern latitude carbon balance in response to global change. Global Change Biology 19: 2022-2035.

Loisel J, Gallego-Sala AV, Yu Z. 2012. Global-scale pattern of peatland Sphagnum growth driven by photosynthetically active radiation and growing season length. Biogeosciences 9: 2737-2746. 
Longton RE. 1992. The role of bryophytes and lichens in terrestrial ecosystems. In: Bates JW, Farmer AM, eds. Bryophytes and Lichens in a Changing Environment. Oxford: Clarendon Press, 32-76.

Longton RE. 1997. The role of bryophytes and lichens in polar ecosystems. Special Publication-British Ecological Society 13: 69-96.

Maxwell K, Johnson GN. 2000. Chlorophyll fluorescence-a practical guide. Journal of Experimental Botany 51: 659-668.

McDaniel SF. 2005. Genetic correlations do not constrain the evolution of sexual dimorphism in the moss Ceratodon purpureus. Evolution 59: 2353-2361.

McDaniel SF, Atwood J, Burleigh JG. 2011. Recurrent evolution of dioecy in bryophytes. Evolution.

McDaniel SF, Perroud P-F. 2012. Invited perspective: bryophytes as models for understanding the evolution of sexual systems. The Bryologist 115: 1-11.

McDaniel SF, Shaw AJ. 2005. Selective sweeps and intercontinental migration in the cosmopolitan moss Ceratodon purpureus (Hedw.) Brid.: SELECTION AND MIGRATION IN CERATODON. Molecular Ecology 14: 1121-1132.

McDaniel SF, Willis JH, Shaw AJ. 2007. A linkage map reveals a complex basis for segregation distortion in an interpopulation cross in the moss Ceratodon purpureus. Genetics 176: 2489-2500.

Nicolson SW, Nepi M, Pacini E (Eds.). 2007. Nectaries and Nectar. Dordrecht: Springer Netherlands.

Paolillo DJ Jr. 1979. On the Lipids of the Sperm Masses of Three Mosses. The Bryologist 82: 93-96.

Parke JL, Linderman RG. 1980. Association of vesicular-arbuscular mycorrhizal fungi with the moss 1898-1904. Funaria hygrometrica. Canadian Journal of Botany $\mathbf{5 8}$ :

Petry WK, Perry KI, Fremgen A, Rudeen SK, Lopez M, Dryburgh J, Mooney KA. 2013. Mechanisms underlying plant sexual dimorphism in multi-trophic arthropod communities. Ecology 94: 2055-2065.

Pfeffer W. 1884. Locomotorische Richtungsbewegungen durch die chemische Reize. Untersuchungen Bot. Inst. Tübingen: 363-482. 
Pilloni G, Granitsiotis MS, Engel M, Lueders T. 2012. Testing the Limits of 454 Pyrotag Sequencing: Reproducibility, Quantitative Assessment and Comparison to T-RFLP Fingerprinting of Aquifer Microbes (S Bertilsson, Ed.). PLoS ONE 7: e40467.

Pressel S. 2009. The illustrated moss flora of Antarctica. Annals of Botany 104: vivii.

Pressel S, Bidartondo MI, Ligrone R, Duckett JG. 2014. Fungal symbioses in bryophytes: New insights in the Twenty First Century. Phytotaxa 9: 238-253.

Ptaszyńska A, Mułenko W, Żarnowiec J. 2009. Bryophytes microniches inhabited by microfungi. Annales UMCS, Biologia 64.

Rabatin SC. 1980. The Occurrence of the Vesicular-Arbuscular-Mycorrhizal Fungus Glomus tenuis with Moss. Mycologia 72: 191-195.

Read DJ, Duckett JG, Francis R, Ligrone R, Russell A. 2000. Symbiotic fungal associations in 'lower' land plants. Philosophical Transactions of the Royal Society B: Biological Sciences 355: 815-831.

Renner SS, Ricklefs RE. 1995. Dioecy and Its Correlates in the Flowering Plants. American Journal of Botany 82: 596.

Renzaglia KS, Garbary DJ. 2001. Motile Gametes of Land Plants: Diversity, Development, and Evolution. Critical Reviews in Plant Sciences 20: 107-213.

Rosenstiel TN, Shortlidge EE, Melnychenko AN, Pankow JF, Eppley SM. 2012. Sex-specific volatile compounds influence microarthropod-mediated fertilization of moss. Nature 489: 431-433.

Rousk K, Jones DL, DeLuca TH. 2014. Moss-nitrogen input to boreal forest soils: Tracking $15 \mathrm{~N}$ in a field experiment. Soil Biology and Biochemistry 72: 100-104.

Rubinstein CV, Gerrienne P, de la Puente GS, Astini RA, Steemans P. 2010. Early Middle Ordovician evidence for land plants in Argentina (eastern Gondwana). New Phytologist 188: 365-369.

Schöb C, Butterfield BJ, Pugnaire FI. 2012. Foundation species influence traitbased community assembly. New Phytologist 196: 824-834.

Schütte UME, Abdo Z, Bent SJ, Shyu C, Williams CJ, Pierson JD, Forney LJ. 2008. Advances in the use of terminal restriction fragment length polymorphism (T-RFLP) analysis of 16S rRNA genes to characterize microbial communities. Applied Microbiology and Biotechnology 80: 365-380. 
Shaw J, Beer SC. 1999. Life history variation in gametophyte populations of the moss Ceratodon purpureus (Ditrichaceae). American Journal of Botany 86: 512-521.

Shaw AJ, Cox CJ, Goffinet B. 2005. Global patterns of moss diversity: taxonomic and molecular inferences. Taxon: 337-352.

Shaw AJ, Gaughan JF. 1993. Control of Sex Ratios in Haploid Populations of the Moss, Ceratodon purpureus.pdf. American Journal of Botany 80: 584-591.

Shaw AJ, Szovenyi P, Shaw B. 2011. Bryophyte diversity and evolution: Windows into the early evolution of land plants. American Journal of Botany 98: 352-369.

Shuster SM, Lonsdorf EV, Wimp GM, Bailey JK, Whitham TG. 2006. Community heritability measures the evolutionary consequences of indirect genetic effects on community structure. Evolution; international journal of organic evolution 60: 9911003.

Skotnicki ML, Mackenzie AM, Ninham JA, Selkirk PM. 2004. High levels of genetic variability in the moss Ceratodon purpureus from continental Antarctica, subantarctic Heard and Macquarie Islands, and Australasia. Polar Biology 27: 687698.

Stark LR. 2002. Phenology and its repercussions on the reproductive ecology of mosses. The Bryologist 105: 204-218.

Stark LR, McLetchie DN, Eppley SM. 2010. Sex ratios and the shy male hypothesis in the moss Bryum argenteum (Bryaceae). The Bryologist 113: 788-797.

Stenroos S, Laukka T, Huhtinen S, Döbbeler P, Myllys L, Syrjänen K, Hyvönen J. 2009. Multiple origins of symbioses between ascomycetes and bryophytes suggested by a five-gene phylogeny. Cladistics 26: 281-300.

Stuiver BM, Gundale MJ, Wardle DA, Nilsson M-C. 2015. Nitrogen fixation rates associated with the feather mosses Pleurozium schreberi and Hylocomium splendens during forest stand development following clear-cutting. Forest Ecology and Management 347: 130-139.

Tovar-Sánchez E, Oyama K. 2006. Effect of hybridization of the Quercus crassifolia $x$ Quercus crassipes complex on the community structure of endophagous insects. Oecologia 147: 702-713.

Tuba Z, Slack NG, Stark LR. 2011. Bryophyte Ecology and Climate Change. Cambridge University Press.

Turetsky MR. 2003. The role of bryophytes in carbon and nitrogen cycling. The Bryologist 106: 395-409. 
Turetsky MR, Bond-Lamberty B, Euskirchen E, Talbot J, Frolking S, McGuire AD, Tuittila E-S. 2012. The resilience and functional role of moss in boreal and arctic ecosystems. New Phytologist 196: 49-67.

Turetsky M, Wieder K, Halsey L, Vitt D. 2002. Current disturbance and the diminishing peatland carbon sink. Geophysical Research Letters 29: 21-1.

Vanderpoorten A, Goffinet B. 2009. Introduction to Bryophytes. Cambridge University Press.

Varga S. 2010. Effects of arbuscular mycorrhizas on reproductive traits in sexually dimorphic plants. Spanish Journal of Agricultural Research 8: 11-24.

Vega-Frutis R, Munguía-Rosas MA, Varga S, Kytöviita M-M. 2013. Sex-specific patterns of antagonistic and mutualistic biotic interactions in dioecious and gynodioecious plants. Perspectives in Plant Ecology, Evolution and Systematics 15: 45-55.

Vellend M. 2010. Conceptual synthesis in community ecology. The Quarterly Review of Biology 85: 183-206.

Wang B, Yeun LH, Xue J-Y, Liu Y, Ané J-M, Qiu Y-L. 2010. Presence of three mycorrhizal genes in the common ancestor of land plants suggests a key role of mycorrhizas in the colonization of land by plants. New Phytologist 186: 514-525.

Weiher E, Keddy P (Eds.). 2001. Ecological Assembly Rules: Perspectives, Advances, Retreats. Cambridge University Press.

Wellman CH, Gray J. 2000. The microfossil record of early land plants. Philosophical Transactions of the Royal Society of London B: Biological Sciences 355: 717-732.

Whitham TG, Bailey JK, Schweitzer JA, Shuster SM, Bangert RK, LeRoy CJ, Lonsdorf EV, Allan GJ, DiFazio SP, Potts BM, et al. 2006. A framework for community and ecosystem genetics: from genes to ecosystems. Nature Reviews Genetics 7: 510-523.

Whitham TG, Young WP, Martinsen GD, Gehring CA, Schweitzer JA, Shuster SM, Wimp GM, Fischer DG, Bailey JK, Lindroth RL, et al. 2003. Community and ecosystem genetics: a consequence of the extended phenotype. Ecology 84: 559573.

Wimp GM, Martinsen GD, Floate KD, Bangert RK, Whitham TG, Williams CF. 2005. Plant genetic determinants of arthropod community structure and diversity. Evolution 59: 61-69. 
Wyatt R, Anderson LE. 1984. Breeding systems in bryophytes. The experimental biology of bryophytes. London, U.K.: Academic Press, 39-64.

Zhang Y, Guo L-D. 2007. Arbuscular mycorrhizal structure and fungi associated with mosses. Mycorrhiza 17: 319-325.

Ziegler H, Kaiser K, Lipp J. 1988. Sucrose in the archegonium exudate of the mossBryum capillare Hedw. Naturwissenschaften 75: 203-203. 